\title{
Tick Size and Informed Trading: Evidence from the Taiwanese Stock Market
}

\author{
Chang-Wen Duan ${ }^{1}$, Ken Hung ${ }^{2}, \&$ Shinhua Liu $^{3}$ \\ ${ }^{1}$ Department of Banking and Finance, Tamkang University, New Taipei city, Taiwan \\ ${ }^{2}$ Sanchez School of Business, Texas A\&M International University, Laredo, TX, United States \\ ${ }^{3}$ College of Business, University of Southern Mississippi, Hattiesburg, MS, United States \\ Correspondence: Shinhua Liu, College of Business, University of Southern Mississippi, Hattiesburg, MS 39406, \\ United States.
}

Received: November 4, 2021

Accepted: November 23, 2021

Online Published: November 25, 2021

doi:10.5539/ibr.v15n1p1

URL: https://doi.org/10.5539/ibr.v15n1p1

\begin{abstract}
We adopt the Sandås model for order-book equilibrium to examine informed trading on the Taiwanese stock market, a purely order-driven call-auction market. We find that adverse-selection cost is low for well-known stocks with high liquidity and low volatility, but cost is high for monitoring the order books of those stocks. Our empirical results show that the impact of adverse selection is greatest at the beginning of each trading day and that informed traders engage in stealth trading, supporting the stealth trading hypothesis. Finally, with the special tick size rules on the market, both adverse-selection cost and monitoring cost decline as tick size decreases.
\end{abstract}

Keywords: adverse selection, informed trading, tick size, stealth trading hypothesis, panel data model

\section{Introduction}

Securities markets around the world differ in their source of liquidity supply. In a quote-driven market liquidity is supplied by market makers; in an order-driven market liquidity supply relies on the limit orders submitted by traders; and in a hybrid market designated specialists and limit orders together play the role of supplying liquidity. Developing securities markets typically adopt a quote-driven system, in which brokers or dealers offer quotes on bid/ask prices, with corresponding quantities according to their own needs or the requests of investors. But with advancements in information technology and the opening of financial markets, the auction system has been gradually replaced by electronic trading systems, which execute trades by matching prices in the electronic limit order book, without an intermediary. Aside from making order placement more convenient, electronic trading systems feature faster and more efficient trade execution as compared to manual matching in a quote-driven market. They also aid the flow and transmission of trading information. Among the markets that have adopted electronic trading systems, some are purely order-driven; some use floor-based traders; (Note 1) and the others are a hybrid of the order-driven and quote-driven systems.

There is a wealth of literature on issues related to quote-driven markets, but relatively little on order-driven markets. In addition, the majority of articles that address order-driven markets employ the same methodologies used in the study of quote-driven markets. Owing to lack of consideration for order book equilibrium in order-driven markets, these articles report mainly insignificant or inconsistent empirical results. In contrast, this paper considers order book equilibrium and uses order book data to investigate relationships among liquidity, volatility and trading costs. It may not be difficult to characterize these relationships using empirical studies on quote-driven markets. For instance, Huang and Stoll (1994) and Chan, Christie, and Schultz (1995) use bid-ask spread to examine the information content of markets. The empirical results from the information-based models generally show that high liquidity is accompanied by low bid-ask spread and that implied liquidity is a key determinant of bid-ask spread. However, it is doubtful that using the bid-ask spread approach to decompose information content is applicable to an order-driven market.

Studies that sample order book data find incongruence between empirical and modeling results, hence casting doubt on the validity of the theoretical predictions. Some such studies propose that the incongruent empirical results are attributable to inconsistent assumptions made in the model and to the actual trading process, or that the modeling conditions are too restrictive. Sandås (2001) extends the Glosten (1994) model and uses the order 
book equilibrium process in an order-driven market to develop a limit order book model for estimating order size, trading cost and adverse selection cost. Furthermore, the Sandås (2001) model assumes an exponential distribution of market order quantity, resulting in liquidity supply equations with closed-form solutions through setting moment conditions for the generalized method of moment (GMM) estimation. Differing from the two best bid/ask quotes used by Sandås (2001), the Taiwan Stock Exchange (TWSE) changed its bid/ask disclosure rules by offering prices and volumes of unexecuted orders at the five best bid/ask prices with corresponding quantities instead of just one best bid/ask quote on January 2, 2003. Thus, the data we use are more complete in comparison with the order book data used in prior literature.

This paper examines the impact of tick size on trading behavior of informed traders in stocks listed on the TWSE. The issue of how tick size affects informed trading is important for the design of a market trading mechanism with efficiency. The TWSE changed the tick size of all listed stocks on March 1, 2005. Because the tick size of TWSE-listed stocks is determined by their transaction price, the effect of tick size change on the trading behavior of informed traders is expected to be different. Moreover, it is unclear ex ante whether the incentive for gathering information will increase or decrease under changed tick size rule. While previous studies investigate the impact of tick size reduction on market quality and the information content of the order book, no research has looked into the influence of tick size change on the information content of a purely order-driven call auction market. This paper attempts to fill this void.

After considering the effect of the tick size change on the trading behavior of investors, we then employ the same samples in two periods to carry out the following four analyses. First, we use a large sample to estimate the parameters of the Sandås (2001) model. Next, assuming that better performing investors tend to have particular preferences in the stocks and times they select to trade, we classify the samples by their Exchange Traded Funds (ETF) category and trading time to investigate the preferences of informed traders in stock selection and timing of trades. Third, we discuss how tick size variation affects informed trading behavior in connection with the special TWSE rule of setting tick size on the basis of transaction price. Finally, we design four informed-trader proxies to conduct two-stage regressions and panel data modeling to confirm the order placement behavior of informed traders.

Our efforts could contribute to the literature in the following ways. First, while existing analysis of the effects of tick-size adjustment focuses on quote-driven markets, this paper examines the impacts of changing minimum tick size on a purely order-driven call-auction market. Also different from the prior literature that focuses on tick size reduction, this study comprehensively covers all three cases: decrease, no change, and increase in tick size. Second, instead of the traditional bid-ask spread evaluation method, this study adopts an order-book equilibrium model at the five best bid/ask prices with corresponding quantities to discuss the effect of informed trading. Finally, the data we use are more complete in comparison with the order book data used in the previous studies. In addition to using order-book information, we also consider the potential effects of the tick size change on market participants around the event day.

Our empirical results show that the order processing cost is negative, indicating that a trader needs to incur a cost to monitor the order book when he submits an order. With increased market transparency, the adverse selection cost, order submission cost, liquidity, and volatility are also improved, whereas quantity of submitted orders worsens. The empirical results using intraday data reveal that the adverse selection cost and monitoring cost are highest at the beginning of the trading day, suggesting that informed traders prefer to submit orders at that time of day. The cost incurred by investors to monitor the orders they submit is also highest at the beginning of the trading day. We also find that increased information transparency and visibility of the stock, in addition to tick size reduction, help to reduce the adverse selection cost and monitoring cost. Finally, our results demonstrate that data from the TWSE support the stealth trading hypothesis, consistent with Barclay and Warner (1993) and Sandås (2001), confirming that net buying pressure also influences the adverse selection cost.

The remainder of this paper is organized as follows. The following section reviews the literature about tick size and informed trading. In Section 3 we introduce the TWSE trading system. Section 4 presents the order book equilibrium model used in this paper. Section 5 describes the sample, data, definitions of variables and methodologies used. Section 6 reports the empirical results, and Section 7 concludes the study.

\section{The Literature about Informed Trading and Tick Size}

Bagehot (1971), Copeland and Galai (1983), and Glosten and Milgrom (1985) postulate that there are informed traders and uninformed traders in the securities markets. Informed traders know the true value of a stock and are able to correctly judge its path of movement. Thus, well-informed traders would engage in trading based on the private information they own. Hence when a market maker trades with an informed trader, information 
asymmetry would cause a loss to the market maker, which is defined as "adverse selection cost." In such a case, the market maker would charge an information rent from uninformed traders to make up for his loss incurred from trading with the informed trader. In a purely order-driven market, every participant that submits an order plays the dual roles of a market maker and an investor, which make an informed trader one of the market makers. In that event, the probability of an adverse selection should theoretically be lower than in a quote-driven market. Pagano and Roell (1996) assert that in an order-driven market where more information is made available to the public, trading cost is far lower than in a less-transparent, quote-driven market, implying that both adverse selection cost and order processing cost should be lower in an order-driven market. Thus, we believe that in an order-driven market, there is a strong link between the order size submitted by an informed trader and the adverse selection cost.

However, Madhavan (1996) argues that in a market with poor liquidity and greater information transparency, noise traders would withdraw from the market, resulting in more sensitive prices, lower market liquidity, higher price volatility, and increased trading costs for liquidity traders. Bloomfield, O'Hara, and Saar (2005) find that informed traders use more limit orders than liquidity traders do. Furthermore, they show that liquidity provision shifts over time, with informed traders increasingly providing liquidity in the markets. These findings suggest significant links among liquidity, volatility and trading costs.

When information asymmetry is severe or when liquidity supply and demand is high, there is often a rise in trading volume and bid-ask spread in a quote-driven market. In an order-driven market, the information content of such trading behavior would be clearly revealed in the equilibrium of order books (Griffiths, Smith, Turnbull, \& White, 2000). Thus, using order-book data to look into the information content of trades could capture potentially more valuable information than using transaction data.

In recent years, many well-known exchanges gradually adopted measures that reduced minimum tick size. For example, the NYSE, AMEX, and NASDAQ have all reduced minimum tick size several times. This has spurred a lot of interest in the effects of minimum price variation on market quality. Prior studies show that tick size affects the trading behavior of informed traders. For example, Gibson, Singh, and Yerramilli (2003) find that the effects of decimalization on the behavior of informed traders are opaque and that the likelihood of adverse selection would rise after decimalization. Bollen, Smith, and Whaley (2004) also find that the relative impact of adverse selection on spreads increases after decimalization, when using options theory to estimate the spread components on the NASDAQ. Likewise, Zhao and Chung (2006) and Chakravarty, Van Ness, and Van Ness (2005) report similar results for stocks on the NYSE. However, these studies are based on quote-driven market data.

According to Comerton-Forde, and Rydge (2006), in the Asia/Pacific region, only stock exchanges in Malaysia and Taiwan utilize the call market method as the sole price and order matching method. Yet, few studies have examined tick size changes in these markets. For instance, Ke, Jiang, and Huang (2004) study the impact of tick size for stocks listed on the TWSE, but they do not focus on tick size changes. While Chen and Gau (2009) investigate the impact of tick size reduction in Taiwan, their focus is on stock index, index futures, and index options.

According to the prior literature (Zhao \& Chung, 2006, and Gibson, Singh, \& Yerramilli, 2003, and Harris, 1998), we believe that smaller tick size narrows the spread, whereas the effect of smaller spread on the adverse selection cost of information-based trading can be attributed to two offsetting forces. When the tick size is too large, it not only imposes a greater fixed cost on informed traders but also increases the probability of the spread straddling the efficient price, thus reducing traders' incentive for obtaining information. Hence, any drop in tick size owing to decreased trader rents ought to increase informed trading, resulting in higher adverse selection cost. Yet, this effect may be mitigated by the price and time priority rule. (Note 2) A large minimum tick size protects informed traders from front running and order jumping by floor traders. Smaller tick size benefits floor traders by reducing the cost of such order jumping. Decreasing tick size can thus reduce the profits from informed trading, reducing traders' incentive for obtaining information. In short, the level of informed trading after a tick size change is, we believe, an empirical question that we attempt to answer through the Sandås (2001) analysis.

Much of the literature offers different views on the order placement behavior of informed traders. Barclay and Warner (1993) reports that informed traders tend to avoid placing large or small orders, thereby supporting the stealth-trading hypothesis. Chakravarty (2001) also finds that institutional investors place medium-size orders to satisfy their need for stealth trading. But Easley and O'Hara (1987) counters that informed traders favor placing large orders. Easley and O'Hara (1992) points out that longer trading interval implies lower probability of informed trading. However, Sandås (2001) finds inconsistent results when using the interval of the last 
transaction of the day to observe the order placement behavior of informed traders. Thus, we believe that informed traders choose not only order quantity but also order submission time. Accordingly, in this paper, we design four proxy variables for the informed trader.

\section{The TWSE Trading System}

The TWSE is a purely order-driven market that does not utilize designated market makers. The trading system of the TWSE operates in a consolidated limit order book environment where only limit orders are accepted. (Note3) Investors submit their orders to the Computer Assisted Trading System (CATS) through brokers. The order price placed by an investor must fall within $\pm 7 \%$ of the stock's previous day closing price to be accepted by the CATS The TWSE trading hours are 9:00am to $13: 30 \mathrm{pm}$, with the opening price determined by the results of a call auction of all orders submitted between 8:30am and 9:00am. The TWSE conducts call auctions once every 45 seconds (Note 4) after opening, during which orders are sequentially accepted by the computer and matched based on a price-time priority rule through the same mechanism in effect at the open to maximize trading volume. The electronic trading system of the TWSE contains several terminals to handle order matching. In general, one terminal handles the trading of 12 to 16 stocks. The principle for allocating stocks to terminals is to smooth out the computer workload and to give equal trading opportunity for different terminals. Therefore, each terminal will handle both active and inactive stocks. For each terminal, daily trading is divided into many trading cycles. In principle, each cycle lasts for 90 seconds during our sample period. In a given cycle, each stock in principle will be matched at least once, but active stocks can be matched twice. For an active stock, there is a call back design. Normally an active stock is executed in every 45 seconds. However, immediately following the execution, there will be an automatic call back after six seconds so that the entered orders during the six seconds can be executed again. So, the minimum possible duration for an active stock is 6 seconds.

On July 1, 2002, the TWSE eliminated the two up/down tick rule (Note 5) so that the matching system changes from a call auction to a continuous auction. On January 2, 2003, the TWSE changed its bid/ask disclosure rules by offering prices and volumes of unexecuted orders at the five best bid/ask quotes so that market participants can make an informed decision when placing orders. Thus, the liquidity on the TWSE responds to the orders submitted by market participants. Also, market participants pay a monitoring cost regardless of if the orders they submit can be filled at the best price; and this cost is determined by the limit order book. On March 1, 2005, the TWSE changed the minimum price variation (tick size) rule by increasing the price intervals. Because tick size is determined by the transaction price of the stock, this change resulted in three groups in the following sample period: samples with tick size reduced (Reduce), samples with tick size unchanged (Unchanged), and samples with tick size increased (Increase). The price intervals and tick sizes around the tick size change are depicted in Table 1.

Table 1. A Snapshot of the Taiwanese stock market

\begin{tabular}{|c|c|c|c|}
\hline Item & Initial-period (1) & Later-period (2) & $\begin{array}{c}\text { Change } \\
{[(2)-(1)] /(1)}\end{array}$ \\
\hline Trading Value (in Billion NT\$) & $6,870.44$ & $11,113.28$ & $61.75 \%$ \\
\hline Trading Volume (Billion Shares) & 327.40 & 317.98 & $-2.88 \%$ \\
\hline No. of Active Investors & $2,615,829$ & $3,173,937$ & $21.34 \%$ \\
\hline No. of Listed Firms & 669 & 698 & $4.33 \%$ \\
\hline \multicolumn{4}{|c|}{ Percentage $(\%)$ of Total Trading Amounts } \\
\hline 1. Institutional Investors & 20.9 & 34.8 & $66.51 \%$ \\
\hline 2. Individual Investors & 79.1 & 65.2 & $-17.57 \%$ \\
\hline P/E Ratio & 24.76 & 15.31 & $-38.17 \%$ \\
\hline Turnover Ratio (\%) & 190.82 & 153.28 & $-19.67 \%$ \\
\hline Tick size & \multicolumn{2}{|c|}{ Transaction price range } & \\
\hline 0.01 & $0.01-5.00$ & $0.01-10.00$ & \\
\hline 0.05 & $5.00-15.00$ & $10.00-50.00$ & \\
\hline 0.10 & $15.00-50.00$ & $50.00-100.00$ & \\
\hline 0.50 & $50.00-150.00$ & $100.0-500.0$ & \\
\hline 1.00 & $150.00-1000$ & $500-1000$ & \\
\hline 5.00 & $>1000$ & $>1000$ & \\
\hline
\end{tabular}

Note. Initial-period represents the sample period before the Taiwan Stock Exchange (TWSE) changed the tick size rule, the period between Feb 6, 2003 and Jun 30, 2003. Later-period represents the sample period after the TWSE changed the tick size rule, the period between Feb 26, 2007 and Jul 18, 2007. 
According to the World Federal of Exchange, the TWSE ranked 13th in 2003 and 21st in 2007 among world exchanges by domestic market capitalization, but its market turnover in terms of trading value was as high as $205.5 \%$ in 2003 and 159.91 in 2007, which seem to be excessively high in comparison with other major exchanges, (Note 6) suggesting high market volatility. The high volatility and high turnover rate of the TWSE might be attributable to the fact that Taiwan's stock markets are dominated by individual traders. Table 1 illustrates the market turnover on the TWSE between 2003 and 2007, showing a decreasing trend in individual trading values. Still, the share of trading accounted for by individual investors remained as high as $65.2 \%$, or $68.0 \%$ if the OTC market was included, quite a departure from the NYSE or NASDAQ, in which institutional investors play a dominant role.

\section{The Structural Model of Order Book}

The TWSE employs an order-driven electronic trading system in which orders are matched following price-time priority rules and on a call auction basis once every 45 seconds (Note 7) in our study periods. The rapid trading frequencies provide an ideal laboratory to apply the Sandås (2001) model in a call market during its transition to a more continuous market. Although the idea of the Sandås (2001) model was derived from a continuous market (the Stockholm Stock Exchange), (Note 8) he rejects the model because actual limit order books are not deep enough to be explained by the model. One possible explanation is that competition among limit-order traders is imperfect, a feature absent in Glosten (1994). As such, Glosten (1994) provides a better reason for us to apply the empirical approach of Sandås (2001) to the case of a call auction market in a limit order book environment, which offers five best bid/ask quotes with corresponding quantities. However, the comparison of call and continuous markets is a very difficult task. (Note 9) Smith, Williams, Bratton and Vannoni (1982) find that contrary to their expectations based on Nash equilibrium, a sealed bid/offer call auction market performs nearly as well as a continuous double-auction market. Overall, the literature presents an inconclusive picture (e.g., Nyborg, Rydqvist, \& Sundaresan, 1997, Smith, 1990, Cox, Smith, \& Walker, 1984, and Isaac \& Walker, 1985). We believe that an electronic trading system with higher matching speed may help resolve these issues. If the trading frequencies in a call market continue to increase, this call market will approach a continuous market. In our sample period, the average trading intervals for initial- and later-periods respectively were 2.651 and 1.97 seconds (as in our Table 7). Comparing the Stockholm Stock Exchange and TWSE from 2003 to 2007 in trading conditions (as in our Appendix A), we conclude that trading frequency is higher in the TWSE than in the Stockholm Stock Exchange. Hence, we believe it is suitable to apply the approach of Sandås (2001) to the TWSE.

The approach of Sandås (2001) differs from the limit order book model of Glosten (1994), which adds discrete price and time priority rules. The Sandås (2001) model suggests an inverse relationship between order book depth and adverse selection cost. The associated empirical methodology is rooted in economic theory, and delivers structural parameter estimates of transaction costs and adverse selection effects in a limit order book market.

Assuming there are market makers and traders in the market, patient market participants supply liquidity by submitting limit orders to wait for the quotes they desire, like a market maker. Traders with private information can enhance liquidity by submitting orders. Sandås (2001) further assumes fundamental asset value $\left(X_{t}\right)$ to be a random walk with innovation depending on market order of size $m$ and the price impact function $\alpha$, i.e., the adverse selection cost parameter. The information link between $\mathrm{m}$ and $X_{t}$ follows a non-decreasing function below:

$$
X_{t+1}=\mu+X_{t}+\alpha m_{t} .
$$

Sandås (2001) further uses a reduced form to represent trader demand for liquidity, assuming that a trader will be a buyer or a seller with equal probability and that the desired market order quantity is exponentially distributed. The probability density function $\mathrm{f}(\mathrm{m})$ is as follows:

$$
f\left(m_{t}\right)=\left\{\begin{array}{ll}
\frac{1}{2 \lambda} e^{-\frac{m_{t}}{\lambda}} & \text { if } m_{t}>0 \\
\frac{1}{2 \phi} e^{\frac{m_{t}}{\phi}} & \text { if } m_{t}<0
\end{array}\right\},
$$

where $\lambda$ and $\psi$ the expected market order quantity for buyers and sellers, respectively; $\mathrm{m}$ is positive for a buy 
order and negative for a sell order.

Risk-neutral market makers (limit order traders) are assumed to incur a quantity-invariant order processing cost $(\gamma)$, and have knowledge about the distribution of market order size and the adverse selection component $\alpha$, but not about the true asset price. They choose limit order prices and quantities such that their expected profit is maximized. If the last unit at any discrete price tick exactly breaks even, i.e., has zero expected profit, the order book is in equilibrium.

As such, we denote the ordered discrete price ticks on the ask side by $\mathrm{p}_{+\mathrm{k}}$, and on the bid side by $\mathrm{p}_{-\mathrm{k}}$, with $\mathrm{k}=1, \ldots$, 5 , and with the associated order quantities at those prices equal to, respectively, $\mathrm{q}_{+\mathrm{k}}$ and $\mathrm{q}_{-\mathrm{k}}$. Under the assumption that $\mathrm{q}_{0, \mathrm{t}} \equiv 0$, the equilibrium order book at time $\mathrm{t}$ can recursively be constructed as follows:

Ask side:

$$
q_{+k, t}=\frac{p_{+k, t}-X_{t}-\mu-\gamma}{\alpha}-Q_{+k-1, t}-\lambda \quad k=1,2,3,4,5
$$

Bid side:

$$
q_{-k, t}=\frac{X_{t}+\mu-p_{-k, t}-\gamma}{\alpha}-Q_{-k+1, t}-\phi \quad k=1,2,3,4,5
$$

where $Q_{+k, t}=\sum_{i=+1}^{+k} q_{i, t}$ and $Q_{-k, t}=\sum_{i=-1}^{-k} q_{i, t}$. The two equations above contain the model's key point, that is, order depth and informativeness of order flow are inversely related. If the model represent the real-world trading process well and consistent estimates of model parameters can be obtained, we can use Equation (4) to predict the evolution of the order book for a given stock, quantify the adverse selection cost, and depict the effect of an order on order book depth.

\section{Sample, Data, and Methodologies}

\subsection{Samples and Data}

The intraday transaction and order data for all TWSE-listed stocks are included for analysis. Considering the potential effects of the TWSE's tick size change on market participants, we use two sample periods around the event day (March 1, 2005): the pre-event period $(2 / 6 / 2003 \sim 6 / 30 / 2003)$ and the post-event period $(2 / 26 / 2007$ 7/18/2007), (Note 10) with each period covering 100 trading days. According to the prior literature, changed trading rules will affect the trading behavior of investors, but it will take some time. Moreover, because tick size of the TWSE listed firms is determined by transaction price, whether tick size is changed or not would be determined by the prevailing price after the change in tick size rule. Therefore, the change in tick size rule may not have immediate impact on some individual stocks. Such a sampling method allows us to compare trading behavior around the event.

Because the TWSE system conducts call auctions once every 45 seconds during trading hours, we use multiples of 45 seconds to obtain stable estimates of realized volatility. We find that the realized volatility for the non-overlapping 45-second multiples of 6, 9, 12, and 30 minutes interval appears to be quite consistent and stable, while the standard deviation of daily realized volatility estimate of 9 minutes interval is lowest. Therefore, we use a particular nine-minute (Note 11) interval to estimate the volatility. Jain and Joh (1988) and Foster and Viswanathan (1993) document empirical evidence of a U-shaped intraday pattern of intraday return volatility. Ke, Jiang, and Huang (2004) provides consistent empirical results from Taiwan. Therefore, we use the nine-minute interval and obtain intraday intervals beginning at 9:09 and ending at 13:21 every day, after removing the nine-minute intervals immediately after market open and before market close, which might interfere with empirical performance. We further divide the sample data by assigning intraday trading intervals into Session A (9:09-10:30), Session B (10:30-12:00), and Session C (12:00-13:21).

Table 2 depicts the grouping of valid non-overlapping samples by ETF attribute into T50 (Taiwan 50 index constituent stocks), (Note 12) T100 (Taiwan 100 index constituent stocks) (Note 13) and OTHER (neither T50 nor T100 constituent stocks). Such a grouping method enables us to clearly distinguish stocks issued by well-established and financially-sound companies. Also included in Table 2 are the statistics of all samples, in which Taiwan Corporate Credit Risk Index (TCRI) is the rating given by Taiwan Economic Journal (TEJ) Co., 
Ltd on individual stocks based on the financial information and risk factors of the listed company. A lower TCRI score means a higher rating for the company and lower credit risk. $\sigma$, CP, TVO, TVA and MV are, respectively, the concentration measure, (Note 14) closing price, trading volume, trading value, and market value of equity. All figures represent the per-stock average of the samples in the group over the period. The table shows that the T50 group had the highest TCRI rating (lowest score), the highest $\sigma$, (Note 15) which represents dispersion of ownership, and the highest trading volume and trading value. The statistics indicate that some investors prefer specific stocks, particularly the T50 constituent stocks, which are well known to investors. The average per share closing price of the T50 group is also the highest. As expected, the tick size of the majority of T50 constituent stocks increased after TWSE changed the tick size for all listed stocks. According to the literature, tick size reduction should lower adverse selection cost. However, well- known stocks tend to have higher turnover because of better market visibility and, as such, possibly lower adverse selection cost. Thus, to observe the investment behavior of informed traders in selecting stocks, we believe the ETF attribute of individual stocks provides more information than individual stocks.

Our raw data are the order and transaction data for stocks listed on the TWSE. To minimize potential contamination, we exclude all stocks that were first listed, delisted, required of full-payment, transferred to the OTC or put on the alert list during a sample period or one month around it. Source data involving inaccurate order placement times, non-trading hours, outlying quote prices, non-positive ask-bid spreads and non-best five bid/ask quotes are also excluded. Because we employ the GMM for parameter estimation, valid samples are subject to the GMM convergence. Thus, the estimates of full sample with less than 50 days of non-convergence and 30 days for session A, B, and C samples are also excluded. As a result, we obtain 360 final empirical samples.

Table 2. Descriptive statistics

\begin{tabular}{|c|c|c|c|c|}
\hline $\begin{array}{c}\text { ETF } \\
\text { Samples }\end{array}$ & Means & Initial-period (1) & Later-period (2) & $\begin{array}{c}\text { Change } \\
{[(2)-(1)] /(1)}\end{array}$ \\
\hline \multirow{6}{*}{$\mathrm{T} 50$} & TCRI (score) & 2.70 & 2.43 & $-10.00 \%$ \\
\hline & $\sigma$ (person) & $54,739.23$ & $54,358.36$ & $-0.70 \%$ \\
\hline & $\mathrm{CP}(\mathrm{NT} \$)$ & 20.16 & 59.41 & $194.69 \%$ \\
\hline & TVO (1000 share) & 457.22 & 351.55 & $-23.11 \%$ \\
\hline & TVA (1000 NT\$) & $13,281.39$ & $19,242.71$ & $44.88 \%$ \\
\hline & MV (million NT\$) & $134,153.08$ & $278,085.93$ & $107.29 \%$ \\
\hline \multirow{6}{*}{$\mathrm{T} 100$} & TCRI (score) & 4.35 & 4.04 & $-7.13 \%$ \\
\hline & $\sigma$ (person) & $21,138.11$ & $21,091.70$ & $-0.22 \%$ \\
\hline & $\mathrm{CP}(\mathrm{NT} \$)$ & 17.73 & 38.66 & $118.05 \%$ \\
\hline & TVO (1000 share) & 264.95 & 243.72 & $-8.01 \%$ \\
\hline & TVA (1000 NT\$) & $5,585.38$ & $7,239.20$ & $29.61 \%$ \\
\hline & MV (million NT\$) & $21,400.33$ & $35,350.95$ & $65.19 \%$ \\
\hline \multirow{6}{*}{ Other } & TCRI (score) & 5.10 & 5.08 & $-0.39 \%$ \\
\hline & $\sigma$ (person) & $7,740.63$ & $7,795.87$ & $0.71 \%$ \\
\hline & $\mathrm{CP}(\mathrm{NT} \$)$ & 14.58 & 23.17 & $58.92 \%$ \\
\hline & TVO (1000 share) & 100.56 & 105.57 & $4.98 \%$ \\
\hline & TVA (1000 NT\$) & $1,696.73$ & $2,472.40$ & $45.72 \%$ \\
\hline & MV (million NT\$) & $5,020.37$ & $7,703.91$ & $53.45 \%$ \\
\hline \multirow{6}{*}{ Full } & TCRI (score) & 4.05 & 3.85 & $-4.94 \%$ \\
\hline & $\sigma$ (person) & $27,872.65$ & $27,748.64$ & $-0.44 \%$ \\
\hline & $\mathrm{CP}(\mathrm{NT} \$)$ & 17.49 & 40.41 & $131.05 \%$ \\
\hline & TVO (1000 share) & 274.24 & 233.61 & $-14.82 \%$ \\
\hline & TVA (1000 NT\$) & $6,854.50$ & 9651.44 & $40.80 \%$ \\
\hline & MV (million NT\$) & $53,524.59$ & $107,046.93$ & $100.00 \%$ \\
\hline
\end{tabular}

Note. Initial-period represents the sample period before the TWSE changed the tick size rule, the period between Feb 6, 2003 and Jun 30, 2003. Later-period represents the sample period after the TWSE changed the tick size rule, the period between Feb 26, 2007 and Jul 18, 2007. ETF samples represent the grouping of valid samples by ETF attribute into T50, T100 and OTHER. TCRI is the rating given by TEJ to individual stocks based on the financial information and risk factors of the listed company. $\sigma, C P, T V O, T V A$ and MV are the standard deviation of the number of shareholders under each percentage ownership group, closing price, trading volume, trading value and market value of equity, respectively. 


\subsection{Parameter Estimation}

Sandås (2001) suggests the use of the GMM developed by Hansen (1982) for parameter estimation. Compared to the maximum likelihood method, the GMM offers the advantages of not requiring a specific distribution and allowing conditional variance and autocorrelation. When applying the GMM, moment restrictions must be constructed. Sandås (2001) assumes zero mean random deviations from order book equilibrium at each price tick and eliminates the unobserved $X_{t}$ in the model by adding the resulting bid/ask side equations for quotes to obtain the following unconditional moment restriction equation:

$$
E\left[p_{+k, t}-p_{-k, t}-2 \gamma-\alpha\left(Q_{k, t}+\lambda+Q_{-k, t}+\phi\right)\right]=0 \quad k=1,2,3,4,5 .
$$

Equation (5) assumes that the marginal limit order at the respective quote has zero expected profit, which is referred to as the "marginal break-even condition." A second set of moment conditions results from eliminating $X_{t}$ by deducting the deviations from equilibrium depths at the $k$ th quote at time $t$ and $t+1$ to meet buyer and seller expectations:

$$
E\left(\Delta p_{ \pm k, t+1}-\alpha\left(Q_{ \pm k, t+1}-Q_{ \pm k, t}\right)-\mu-\alpha m_{t}\right)=0 \quad k=1,2,3,4,5
$$

where $\Delta p_{j, t+1}=p_{j, t+1}-p_{j, t}$; the two equations above are referred to as the "marginal update condition." If the bid/ask orders have different expectations, an additional moment condition is given as follows:

$$
\begin{aligned}
& E\left(m_{t}-\lambda \mid m_{t}>0\right)=0 \\
& E\left(m_{t}+\phi \mid m_{t}<0\right)=0
\end{aligned}
$$

The moment conditions of Sandås (2001) are based mainly on the basic model of Glosten (1994). Glosten (1994) assumes that a limit order trader is an uninformed trader, that is, private information will be disclosed only with the submission of market orders. Several recent articles posit that limit order traders could also be informed traders. For example, Bloomfield, O'Hara, and Saar (2005) reports that informed traders use limit orders more often than liquidity traders. Kaniel and Liu (2006) demonstrate that allowing informed traders to decide optimally on whether to submit limit or market orders can generate equilibria, in which informed traders prefer placing limit orders that are more informative than market orders. As such, the break-even condition and the update condition derived from the assumption that limit order traders are uninformed traders might violate the basic assumptions of the theoretical model, and empirical results obtained from the use of real-world data might reject the theoretical predictions. Hasbrouck (2004) conjectures that the exponential assumption on market order size distribution used in the models of Glosten (1994) and Sandås (2001) may be incorrect. Hasbrouck (2004) implies that this misspecification might be responsible for the empirical discrepancy reported when the model is confronted with real-world data. Undeniably, the exponential assumption is convenient for both theoretical deduction and the application of econometric methodology. It yields the closed form solution for order book equilibrium that can be used conveniently for the GMM estimation.

\subsection{Informed-trading Proxy Variables}

We use a nine-minute interval to estimate the informed trader proxy variable in each interval and obtain a total of 28 intraday intervals after removing the nine-minute interval immediately after market open and before market close, which might interfere with empirical performance. We believe that informed traders choose not only order quantity but also order submission time. Therefore, we design four proxy variables for the informed trader. First, an order with the highest order quantity in each interval is set as an order from an informed trader. The sum of such orders, divided by total order quantity for the day, is denoted as $R_{\text {Max }}^{\text {InformedTader }}$. An order with a quantity within one standard deviation from the mean of the interval is set as an order from an informed trader; the sum of such orders, divided by total order quantity for the day is denoted as $R_{\text {Mid }}^{\text {InformedTader }}$. We average the matching intervals of individual matches across the trading day to obtain the daily average matching interval, which is 
denoted as Time ${ }^{\text {Matching }}$. Finally, the order with the smallest trading interval within the interval is set as an order from an informed trader; the sum of such orders, divided by the total order quantity for the day is denoted as $R_{\text {MinTime }}^{\text {InformedTer }}$.

Bollen and Whaley (2004) define net buying pressure as the difference between the number of buyer-motivated contracts traded each day and the number of seller-motivated contracts traded, and find that net buying pressure provides a good explanation for implied volatility. Likewise, we believe that the variation in the adverse selection cost stems from the imbalance of buy and sell quantities. Thus, we compare the quantities of buy and sell orders. If the size of a buy order is larger than that of a sell order, the volume of the next transaction is defined as buyer-motivated; otherwise, it is defined as seller-motivated. We tally the buyer-motivated and seller-motivated volumes for each day, and subtract the total seller-motivated volume from the total buyer-motivated volume to obtain the net buying pressure volume. The daily net buying pressure volume, divided by the day's total transaction volume, yields the net buying pressure ratio, which is denoted as $R^{N B P}$.

\subsection{Volatility and Liquidity}

Many studies find that the implied information content of return volatility provides an important reference point for investors in determining investment strategy. However, papers that use high-frequency data for empirical study find that the path of intraday data is season-dependent. Thus, seasonality must be eliminated when using intraday data for empirical study (e.g., Engle \& Russell, 1998; Bisirer \& Kamionka, 2000; Bauwens \& Giot, 2001; Bauwens \& Giot, 2003), particularly if market participants tend to treat volatility as an important source of information. According to Andersen and Bollerslev (1998) and Giot and Laurent (2004), after breaking intraday data down into several small intervals, the index derived from the sum of returns within these time intervals can be treated as realized volatility. Thus, we approach the estimation of volatility in the same manner as we treat proxy variables for an informed trader. That is, we compute the log-returns during trading hours at a nine-minute interval and add up the log-returns to obtain the realized volatility $(\sigma)$ below:

$$
\text { RealizdVolatility }_{t}=\sum_{\text {period }_{\text {period }}} r^{2},
$$

where $r_{\text {period }}$ is the log-return in each nine-minute interval. In particular, we distinguish between market ( $\sigma^{\text {market }}$ ) and firm-specific information $\left(\sigma^{\text {stock}}\right)$ in the estimation of volatility in accordance with the findings of Bessembinder, Chan, and Seguin (1996) that traders acquire firm-specific information from the spot market and market information from both the spot and futures markets. The $\sigma^{\text {market }}$ and $\sigma^{\text {stock }}$ are estimated using the Taiwan Stock Exchange Capitalization Weighted Stock Index (TAIEX) and individual stock prices, respectively.

According to Dubofsky and Growth (1984), market liquidity refers to the time it takes to complete a transaction at the current market price or the cost incurred to sell the stock at a specific time. Schwartz (1991) defines liquidity as the ability of individuals to trade quickly at equivalent prices that are reasonable in light of the underlying demand and supply conditions. Massimb and Phelps (1994) view liquidity as the market's ability to provide immediate execution of a trade for buyer and seller. Thus, liquidity can reflect both the speed and cost in the trading process. In the real world, the trading process incurs costs, and liquidity will be one of the key factors influencing such trading costs in circumstances where investors are not able to execute a trade at the prior expected price. Bernstein (1987) indicates that a perfect market should have depth, breadth and resiliency. But these three attributes could lead to conflicting assessments of market liquidity. Baker (1996) asserts that a market might have depth, but not breadth. Thus, we do not consider it appropriate to measure liquidity by depth, breadth and resiliency. In this paper, liquidity is measured using the Amivest Liquidity Ratio, defined as: 


$$
\operatorname{Liq}_{i, t}^{\text {Amivest }}=\sum_{t, j} \frac{P_{j} \times V_{j}}{\Delta_{j} P \% \times 1000},
$$

where $V$ is the trading volume in each session of the day, $\mathrm{P}$ is the trade price in each session of the day, and the denominator represents the percentage of price change. The ratio measures how well a one percent change in price can absorb trading volume. A high value for this ratio means the price change can absorb higher trading volume and higher stock liquidity. The ratio can also be regarded as a liquidity measure that calculates the dollar value of trading that would occur if prices changed by one percent. The Amivest Liquidity Ratio shows how well a stock or investment is able to absorb trading volumes without a significant move in price. A high ratio means that large volumes of stock can be traded with little effect on price.

Table 3. Estimated parameters classified by ETF category

\begin{tabular}{|c|c|c|c|c|c|c|c|}
\hline $\begin{array}{c}\text { ETF } \\
\text { Sample }\end{array}$ & Periods & $\mathrm{N}$ & $\lambda$ & $\varphi$ & $\gamma\left(\times 10^{2}\right)$ & $\alpha\left(\times 10^{3}\right)$ & $\tau\left(\times 10^{2}\right)$ \\
\hline \multirow{3}{*}{ Full } & Initial- ${ }^{(1)}$ & 31533 & $\begin{array}{c}1206.2 \\
(106.27) * * *\end{array}$ & $\begin{array}{c}1287.8 \\
(105.15) * * *\end{array}$ & $\begin{array}{c}-33.68 \\
(-122.61) * * *\end{array}$ & $\begin{array}{l}1.1278 \\
(65.68) * * *\end{array}$ & $\begin{array}{c}8.0262 \\
(279.08) * * *\end{array}$ \\
\hline & Later- $^{(2)}$ & 33377 & $\begin{array}{c}758.6 \\
(74.12) * * *\end{array}$ & $\begin{array}{c}817.5 \\
(71.63) * * *\end{array}$ & $\begin{array}{c}-17.59 \\
(-110.16) * * *\end{array}$ & $\begin{array}{l}1.0652 \\
(61.34) * * *\end{array}$ & $\begin{array}{c}6.2986 \\
(257.02) * * *\end{array}$ \\
\hline & (2)-(1) & -- & $\begin{array}{c}-447.6 \\
(-29.35) * * *\end{array}$ & $\begin{array}{c}-470.3 \\
(-28.13) * * *\end{array}$ & $\begin{array}{c}16.09 \\
(51.33) * * *\end{array}$ & $\begin{array}{l}-0.0626 \\
(-2.56) * *\end{array}$ & $\begin{array}{l}-1.7276 \\
(-45.89) * * *\end{array}$ \\
\hline \multirow{3}{*}{ T50 } & Initial- $^{(1)}$ & 4215 & $\begin{array}{l}3210.3 \\
(51.50) * * *\end{array}$ & $\begin{array}{l}3383.0 \\
(51.69) * * *\end{array}$ & $\begin{array}{c}-56.77 \\
(-52.98) * * *\end{array}$ & $\begin{array}{l}1.1001 \\
(15.14) * * *\end{array}$ & $\begin{array}{c}7.5139 \\
(107.63) * * *\end{array}$ \\
\hline & Later- ${ }^{(2)}$ & 4291 & $\begin{array}{l}1747.1 \\
(61.77) * * *\end{array}$ & $\begin{array}{l}1883.9 \\
(61.25) * * *\end{array}$ & $\begin{array}{c}-34.42 \\
(-43.49) * * *\end{array}$ & $\begin{array}{l}1.0323 \\
(25.50) * * *\end{array}$ & $\begin{array}{c}5.2834 \\
(104.71) * * *\end{array}$ \\
\hline & (2)-(1) & -- & $\begin{array}{l}-1463.2 \\
(-21.50) * * *\end{array}$ & $\begin{array}{l}-1499.2 \\
(-20.85) * * *\end{array}$ & $\begin{array}{c}22.35 \\
(16.82) * * *\end{array}$ & $\begin{array}{r}-0.0678 \\
(-0.82)\end{array}$ & $\begin{array}{l}-2.2304 \\
(-25.96) * * *\end{array}$ \\
\hline \multirow{3}{*}{ T100 } & Initial- ${ }^{(1)}$ & 7835 & $\begin{array}{l}1475.6 \\
(85.25) * * *\end{array}$ & $\begin{array}{l}1575.9 \\
(84.00) * * *\end{array}$ & $\begin{array}{c}-41.56 \\
(-60.55) * * *\end{array}$ & $\begin{array}{l}1.1217 \\
(23.07) * * *\end{array}$ & $\begin{array}{c}8.5233 \\
(139.77) * * *\end{array}$ \\
\hline & Later- ${ }^{(2)}$ & 8291 & $\begin{array}{l}1110.0 \\
(35.31) * * *\end{array}$ & $\begin{array}{l}1188.3 \\
(34.93) * * *\end{array}$ & $\begin{array}{c}-24.66 \\
(-59.53) * * *\end{array}$ & $\begin{array}{l}1.2713 \\
(24.94) * * *\end{array}$ & $\begin{array}{c}6.3139 \\
(130.26) * * *\end{array}$ \\
\hline & (2)-(1) & -- & $\begin{array}{c}-365.6 \\
(-10.03) * * *\end{array}$ & $\begin{array}{l}-387.7 \\
(-9.82) * * *\end{array}$ & $\begin{array}{c}16.90 \\
(21.35) * * *\end{array}$ & $\begin{array}{l}0.1500 \\
(2.12) * *\end{array}$ & $\begin{array}{l}-2.2094 \\
(-28.52) * * *\end{array}$ \\
\hline \multirow{3}{*}{ Other } & Initial- $^{(1)}$ & 19483 & $\begin{array}{c}664.3 \\
(97.92) * * *\end{array}$ & $\begin{array}{c}718.7 \\
(86.86) * * *\end{array}$ & $\begin{array}{c}-25.51 \\
(-106.74) * * *\end{array}$ & $\begin{array}{l}1.1362 \\
(94.90) * * *\end{array}$ & $\begin{array}{c}7.9372 \\
(217.74) * * *\end{array}$ \\
\hline & Later- ${ }^{(2)}$ & 20795 & $\begin{array}{c}414.5 \\
(53.09) * * *\end{array}$ & $\begin{array}{c}449.7 \\
(47.16) * * *\end{array}$ & $\begin{array}{c}-11.29 \\
(-144.77) * * *\end{array}$ & $\begin{array}{l}0.9898 \\
(57.83) * * *\end{array}$ & $\begin{array}{c}6.502 \\
(200.36) * * *\end{array}$ \\
\hline & (2)-(1) & -- & $\begin{array}{c}-249.8 \\
(-24.01) * * *\end{array}$ & $\begin{array}{c}-269.1 \\
(-21.19) * * *\end{array}$ & $\begin{array}{c}14.22 \\
(58.04) * * *\end{array}$ & $\begin{array}{l}-0.1463 \\
(-6.92) * * *\end{array}$ & $\begin{array}{l}-1.4352 \\
(-29.49) * * *\end{array}$ \\
\hline
\end{tabular}

Note. Initial- represents the sample period before the TWSE changed the tick size rule, the period between Feb 6, 2003 and Jun 30, 2003. Later- represents the sample period after the TWSE changed the tick size rule, the period between Feb 26, 2007 and Jul 18, 2007. ETF samples represent the grouping of valid samples by ETF attribute into T50, T100 and OTHER. $\lambda, \varphi, \gamma$, and $\alpha$ are parameters from the Sandås (2001) model. $\tau$ is standardized adverse selection cost proposed by Hasbrouck (1991). All parameter values are the daily averages during the sample period, while the parameter values of grouped samples are derived from averaging the means of individual samples.

$* * *, * *$, and $*$ denote significance at the $0.01,0.05$, and 0.1 levels, respectively. T-statistics are in parentheses. 


\section{Empirical Results}

Table 3 reports the estimation results using the Sandås (2001) approach. All parameter estimates are the daily average during the sample period, while those for grouped samples are averages of the individual samples. The average marginal trading costs are consistent with those reported by Sandås (2001). However, given heterogeneous valuation of an asset, a negative marginal trading cost reflects rational trader behavior when submitting a limit order; it also reflects a trade-off between market (Note 16) and limit orders made by liquidity traders, as well as the order submission cost incurred by the participant. Negative marginal trading cost differs from order processing cost in a quote-driven market, as this cost must be paid when the order is executed, and the participant might tend to adjust the quote on limit orders with lower probabilities of execution. In any case, there is a cost to monitoring limit orders; higher negative value implies higher cost to the participant in monitoring limit orders when their orders are executed.

Comparing the results over time, we find that $\lambda, \varphi$ and $\gamma$ all drop in the later-period, and $\alpha$ drops in the Full, T50 and OTHER groups, but rises in the T100 group. This suggests that after the TWSE implemented the disclosure of five best ask/bid quotes, and market participants gained access to more information under increased market transparency, the cost of monitoring the order book dropped, while the probability of information asymmetry decreased, thereby leading to lower $\alpha$. In addition, the $\alpha$ of the T50 group is lower than that of the T100 group, while its $\gamma$ is higher than that of T100. This could be attributable to the fact that the component stocks of T50 are the top 50 firms in Taiwan by market capitalization, which results in lower $\alpha$. This result also implies that for stocks with higher trading volume and more dispersed ownership, the adverse selection cost is lower. Consistent with Van Ness and Van ness (2005), greater order flow, which is positively correlated with the number of market makers, reduces the adverse-selection costs. But to monitor the order activities of well-known firms, market participants must pay higher monitoring costs.

To compare the adverse selection cost across firms, following Hasbrouck (1991), we standardize the adverse selection cost as follows:

$$
\tau_{i}=\frac{\alpha_{i} \times \bar{V}_{i}}{\bar{P}_{i}}
$$

where $\bar{V}$ is the daily average trading volume of individual samples, and $\bar{P}$ is the daily mean quote midpoint.

The last row of Table 4 gives the average $\tau$ estimate. It is evident that the average $\tau$ in the later-period decreases consistently and that this decrease is statistically significant. T50 constituent stocks have the smallest adverse selection cost, but the magnitude of drop is largest. Such results suggest that aside from increased information transparency, higher trading volume and better visibility for these stocks help to reduce their adverse selection cost.

In Table 4 we report the estimated parameters for three different session groups by daily trading hour to show possible variations across various daily trading intervals. We find that, except for the $\alpha$ estimates in various sessions, which rise in the later-period, all other parameter estimates drop in the later-period as compared to the initial-period. However, as measured by the $\tau$ value, the adverse selection cost estimates all drop in the later-period.

A look at the daily order placement intervals shows that $\lambda$ and $\varphi$ values rise during the time interval from opening to 12:00, and drop during the time interval from 12:00 to closing. However, the intraday movements of $\alpha$ and $\gamma$ are in opposite directions. Moreover, an examination of order placement behavior during various daily sessions reveals that order quantity follows an inverse U-shaped path, while the order submission cost and adverse selection cost exhibit a U-shaped pattern. Also, the $\tau$ estimate shows a negative skew, implying that trading costs are highest at the beginning of the day.

Because the tick size of the TWSE-listed stocks is determined by their transaction price, the later-period samples in this study as compared to the initial-period samples are classified into five groups, that is, -2 range, -1 range, \pm 0 range, +1 range, and +2 range. Table 5 shows the average parameter estimates of the five groups classified by tick size change. It is interesting to note that in terms of the adverse selection and monitoring costs, the $\alpha$ estimate rises for groups with a tick size increase, drops for those with a tick size reduction, and shows no significant change for those with no tick size change, clearly indicating a positive relation between the 
magnitude of tick size variation and informed trading. Smaller tick size narrows the spread, whereas the effect of smaller spread on the adverse selection cost of information-based trading can be attributed to two counter-balancing forces. Our results show that with reduced tick size the TWSE matching mechanism has increased influence on reducing the possibility of adverse selection. As a result, $\alpha$ is decreased. It indicates that effect of increasing traders' incentives for obtaining information is less than the effect of reducing the profits from informed trading after the change in tick size rule. Thus, the matching rule of precedence of price priority and time priority adopted by the TWSE is an important trading rule that minimizes the occurrence of adverse selection.

Furthermore, we find that the $\tau$ values of both \pm 0 range and +1 range groups also drop, indicating that the adverse selection cost per average unit price is improved for stocks whose tick size increases by one range, suggesting that liquidity traders are more active in placing orders on stocks with lower unit cost of adverse selection (with higher $\lambda$ and $\varphi$ ). When tick size increases by two ranges, the impact of information-based trading on the market cannot be entirely offset by the counter-balancing force, resulting in an increase in $\tau$, which is, however, not statistically significant. These results indicate that trading volume, market value, and visibility, in addition to tick size reduction, can reduce the adverse selection cost. Increased information transparency through the disclosure of the prices and quantities of the best five bid/ask quotes also contributes significantly to lowering the adverse selection cost. An observation of the $\gamma$ values also shows that tick size reduction helps to reduce the cost of monitoring the order book.

Table 4. Estimated intraday parameters for the full sample

\begin{tabular}{|c|c|c|c|c|c|c|c|}
\hline Session & Periods & $\mathrm{N}$ & $\lambda$ & $\varphi$ & $\gamma\left(\times 10^{2}\right)$ & $\alpha\left(\times 10^{3}\right)$ & $\tau\left(\times 10^{2}\right)$ \\
\hline \multirow{3}{*}{$\begin{array}{c}\text { Session } \\
\text { A } \\
(9: 09- \\
10: 30)\end{array}$} & Initial- $^{(1)}$ & 22254 & $\begin{array}{l}1115.4 \\
(97.08) * * *\end{array}$ & $\begin{array}{l}3608.7 \\
(57.63) * * *\end{array}$ & $\begin{array}{c}-24.51 \\
(-104.40)\end{array}$ *** & $\begin{array}{l}0.4707 \\
(69.18) * * *\end{array}$ & $\begin{array}{c}2.5851 \\
(225.01) * * *\end{array}$ \\
\hline & Later- ${ }^{(2)}$ & 26507 & $\begin{array}{c}583.3 \\
(70.87) * * *\end{array}$ & $\begin{array}{l}2662.2 \\
(26.85) * * *\end{array}$ & $\begin{array}{c}-13.71 \\
(-98.54) * * *\end{array}$ & $\begin{array}{l}0.6027 \\
(47.99) * * *\end{array}$ & $\begin{array}{c}1.8238 \\
(210.65) * * *\end{array}$ \\
\hline & (2)-(1) & - & $\begin{array}{c}-532.1 \\
(-38.45) * * *\end{array}$ & $\begin{array}{l}-946.5 \\
(-7.73) * * *\end{array}$ & $\begin{array}{c}10.81 \\
(41.04) * * * \\
\end{array}$ & $\begin{array}{l}0.1320 \\
(8.77) * * * \\
\end{array}$ & $\begin{array}{l}-0.7613 \\
(-53.82) * * *\end{array}$ \\
\hline \multirow{3}{*}{$\begin{array}{c}\text { Session } \\
\text { B } \\
(10: 30- \\
12: 00)\end{array}$} & Initial- $^{(1)}$ & 15332 & $\begin{array}{l}1695.0 \\
(88.15) * * *\end{array}$ & $\begin{array}{l}4164.0 \\
(61.51) * * *\end{array}$ & $\begin{array}{c}-33.45 \\
(-85.19) * * *\end{array}$ & $\begin{array}{l}0.3930 \\
(59.37) * * *\end{array}$ & $\begin{array}{c}2.0432 \\
(185.45) * * *\end{array}$ \\
\hline & Later- ${ }^{(2)}$ & 21647 & $\begin{array}{c}838.4 \\
(75.30) * * *\end{array}$ & $\begin{array}{l}2831.0 \\
(25.43) * * *\end{array}$ & $\begin{array}{c}-18.86 \\
(-85.39) * * *\end{array}$ & $\begin{array}{l}0.5483 \\
(46.27) * * *\end{array}$ & $\begin{array}{c}1.4255 \\
(196.01) * * *\end{array}$ \\
\hline & (2)-(1) & - & $\begin{array}{c}-856.6 \\
(-40.98) * * *\end{array}$ & $\begin{array}{l}-1333.0 \\
(-9.25) * * *\end{array}$ & $\begin{array}{c}14.59 \\
(34.57) * * *\end{array}$ & $\begin{array}{l}0.1550 \\
(34.57) * * *\end{array}$ & $\begin{array}{l}-0.6177 \\
(-48.74) * * *\end{array}$ \\
\hline \multirow{3}{*}{$\begin{array}{c}\text { Session } \\
\text { C } \\
(12: 00- \\
13: 21)\end{array}$} & Initial- ${ }^{(1)}$ & 16807 & $\begin{array}{l}1574.8 \\
(88.79) * * *\end{array}$ & $\begin{array}{l}3987.3 \\
(76.18) * * *\end{array}$ & $\begin{array}{c}-32.15 \\
(-87.87) * * *\end{array}$ & $\begin{array}{l}0.4162 \\
(63.70) * * *\end{array}$ & $\begin{array}{c}1.8921 \\
(192.07) * * *\end{array}$ \\
\hline & Later- ${ }^{(2)}$ & 23868 & $\begin{array}{c}808.9 \\
(84.38) * * *\end{array}$ & $\begin{array}{l}2778.8 \\
(26.44) * * *\end{array}$ & $\begin{array}{c}-17.42 \\
(-90.59) * * *\end{array}$ & $\begin{array}{l}0.5393 \\
(46.61) * * *\end{array}$ & $\begin{array}{c}1.2645 \\
(202.48) * * *\end{array}$ \\
\hline & (2)-(1) & -- & $\begin{array}{c}-765.9 \\
(-40.82) * * *\end{array}$ & $\begin{array}{l}-1208.5 \\
(-9.11) * * *\end{array}$ & $\begin{array}{c}14.73 \\
(38.45) * * *\end{array}$ & $\begin{array}{l}0.1230 \\
(8.29) * * *\end{array}$ & $\begin{array}{l}-0.6276 \\
(-56.43) * * *\end{array}$ \\
\hline
\end{tabular}

Note. Initial- represents the sample period before the TWSE changed the tick size rule, the period between Feb 6, 2003 and Jun 30, 2003. Later- represents the sample period after the TWSE changed the tick size rule, the period between Feb 26, 2007 and Jul 18, 2007. $\lambda, \varphi, \gamma$, and $\alpha$ are parameters from the Sandås (2001) model. $\tau$ is standardized adverse selection cost proposed by Hasbrouck (1991). All parameter values are the daily average during the sample period, while the parameter values of grouped samples are derived from averaging the means of individual samples.

**, **, and *denote significance at the 0.01, 0.05, and 0.1 levels, respectively. T-statistics are in parentheses. 
Table 5. Estimated parameters classified by tick size change

\begin{tabular}{|c|c|c|c|c|c|c|c|}
\hline $\begin{array}{c}\text { Tick size } \\
\text { change in } \\
\text { range }\end{array}$ & Periods & $\mathrm{N}$ & $\lambda$ & $\varphi$ & $\gamma\left(\times 10^{2}\right)$ & $\alpha\left(\times 10^{3}\right)$ & $\tau\left(\times 10^{2}\right)$ \\
\hline \multirow{3}{*}{-2} & Initial- ${ }^{(1)}$ & 759 & $\begin{array}{l}1307.4 \\
(25.23) * * *\end{array}$ & $\begin{array}{l}1423.2 \\
(23.94) * * *\end{array}$ & $\begin{array}{c}-31.00 \\
(-23.71) * * *\end{array}$ & $\begin{array}{l}0.9997 \\
(15.32) * * *\end{array}$ & $\begin{array}{l}9.1996 \\
(38.62) * * *\end{array}$ \\
\hline & Later- ${ }^{(2)}$ & 776 & $\begin{array}{c}448.9 \\
(27.77) * * *\end{array}$ & $\begin{array}{l}488.8 \\
(24.74) * * *\end{array}$ & $\begin{array}{c}-5.23 \\
(-27.08) * * *\end{array}$ & $\begin{array}{l}0.3398 \\
(21.32) * * *\end{array}$ & $\begin{array}{l}6.7050 \\
(40.19) * * *\end{array}$ \\
\hline & (2)-(1) & -- & $\begin{array}{r}-858.5 \\
(-15.96) * * * \\
\end{array}$ & $\begin{array}{c}-934.4 \\
(-15.05) * * *\end{array}$ & $\begin{array}{c}25.77 \\
(19.71) * * * \\
\end{array}$ & $\begin{array}{l}-0.6599 \\
(-9.92) * * *\end{array}$ & $\begin{array}{l}-2.4946 \\
(-8.61) * * *\end{array}$ \\
\hline \multirow{3}{*}{-1} & Initial- ${ }^{(1)}$ & 11640 & $\begin{array}{l}1125.6 \\
(60.85) * * *\end{array}$ & $\begin{array}{l}1209.3 \\
(58.20) * * *\end{array}$ & $\begin{array}{c}-36.80 \\
(-79.80) * * *\end{array}$ & $\begin{array}{l}1.1192 \\
(71.02) * * *\end{array}$ & $\begin{array}{c}8.0469 \\
(166.87) * * *\end{array}$ \\
\hline & Later- ${ }^{(2)}$ & 11984 & $\begin{array}{c}721.1 \\
(27.85) * * *\end{array}$ & $\begin{array}{c}774.9 \\
(26.79) * * *\end{array}$ & $\begin{array}{c}-9.95 \\
(-153.31) * * *\end{array}$ & $\begin{array}{l}0.7901 \\
(72.50) * * *\end{array}$ & $\begin{array}{c}6.1866 \\
(145.73) * * *\end{array}$ \\
\hline & (2)-(1) & -- & $\begin{array}{c}-404.5 \\
(-12.65) * * * \\
\end{array}$ & $\begin{array}{c}-434.4 \\
(-12.14) * * *\end{array}$ & $\begin{array}{c}26.85 \\
(58.47) * * * \\
\end{array}$ & $\begin{array}{l}-0.3291 \\
(-17.26) * * *\end{array}$ & $\begin{array}{l}-1.8603 \\
(-29.00) * * *\end{array}$ \\
\hline \multirow{3}{*}{ \pm 0} & Initial- $^{(1)}$ & 17218 & $\begin{array}{l}1296.9 \\
(79.70) * * *\end{array}$ & $\begin{array}{l}1378.1 \\
(80.57) * * *\end{array}$ & $\begin{array}{c}-30.49 \\
(-84.80) * * *\end{array}$ & $\begin{array}{l}1.0407 \\
(43.55) * * *\end{array}$ & $\begin{array}{c}7.9061 \\
(207.12) * * *\end{array}$ \\
\hline & Later- ${ }^{(2)}$ & 18581 & $\begin{array}{c}822.5 \\
(109.24) * * *\end{array}$ & $\begin{array}{c}887.5 \\
(106.67) * * *\end{array}$ & $\begin{array}{c}-18.31 \\
(-92.42) * * *\end{array}$ & $\begin{array}{l}0.9986 \\
(43.11) * * *\end{array}$ & $\begin{array}{c}6.2392 \\
(196.06) * * *\end{array}$ \\
\hline & (2)-(1) & -- & $\begin{array}{c}-474.4 \\
(-27.10) * * *\end{array}$ & $\begin{array}{c}-490.6 \\
(-26.38) * * *\end{array}$ & $\begin{array}{c}12.18 \\
(30.26) * * *\end{array}$ & $\begin{array}{r}-0.0421 \\
(-1.26) \\
\end{array}$ & $\begin{array}{l}-1.6669 \\
(-33.72) * * *\end{array}$ \\
\hline \multirow{3}{*}{+1} & Initial- $^{(1)}$ & 1732 & $\begin{array}{c}878.8 \\
(44.43) * * *\end{array}$ & $\begin{array}{c}940.5 \\
(44.98) * * *\end{array}$ & $\begin{array}{c}-40.70 \\
(-30.96) * * *\end{array}$ & $\begin{array}{l}1.9955 \\
(11.80) * * *\end{array}$ & $\begin{array}{l}8.6451 \\
(76.99) * * *\end{array}$ \\
\hline & Later- $^{(2)}$ & 1839 & $\begin{array}{c}543.3 \\
(53.87) * * *\end{array}$ & $\begin{array}{c}586.7 \\
(49.32) * * *\end{array}$ & $\begin{array}{c}-54.72 \\
(-34.15) * * *\end{array}$ & $\begin{array}{l}3.0375 \\
(16.87) * * *\end{array}$ & $\begin{array}{l}7.3259 \\
(69.37) * * *\end{array}$ \\
\hline & (2)-(1) & -- & $\begin{array}{c}-335.5 \\
(-15.37) * * * \\
\end{array}$ & $\begin{array}{c}-353.9 \\
(-14.93) * * *\end{array}$ & $\begin{array}{l}-14.02 \\
(-6.72) * * *\end{array}$ & $\begin{array}{l}1.0420 \\
(4.21) * * * \\
\end{array}$ & $\begin{array}{r}-1.3191 \\
(-8.57) * * * \\
\end{array}$ \\
\hline \multirow{3}{*}{+2} & Initial- $^{(1)}$ & 184 & $\begin{array}{c}482.2 \\
(19.76) * * *\end{array}$ & $\begin{array}{c}524.4 \\
(19.68) * * *\end{array}$ & $\begin{array}{c}-79.53 \\
(-14.94) * * *\end{array}$ & $\begin{array}{l}2.1803 \\
(19.53) * * *\end{array}$ & $\begin{array}{l}7.2990 \\
(25.00) * * *\end{array}$ \\
\hline & Later- ${ }^{(2)}$ & 197 & $\begin{array}{l}242.7 \\
(28.83) * * *\end{array}$ & $\begin{array}{c}261.9 \\
(28.60) * * *\end{array}$ & $\begin{array}{l}-116.60 \\
(-45.48) * * *\end{array}$ & $\begin{array}{l}8.5269 \\
(25.43) * * *\end{array}$ & $\begin{array}{l}7.5257 \\
(24.72) * * *\end{array}$ \\
\hline & (2)-(1) & -- & $\begin{array}{l}-239.5 \\
(-9.53) * * *\end{array}$ & $\begin{array}{l}-262.6 \\
(-9.57) * * *\end{array}$ & $\begin{array}{l}-37.04 \\
(-6.40) * * *\end{array}$ & $\begin{array}{l}6.3470 \\
(17.47) * * *\end{array}$ & $\begin{array}{r}0.2270 \\
(0.54) \\
\end{array}$ \\
\hline
\end{tabular}

Note. The estimated parameters are classified by the TWSE tick size change into five groups: -2 range, -1 range, \pm 0 range, +1 range, and +2 range. Initial- represents the sample period before the TWSE changed the tick size rule, the period between Feb 6, 2003 and Jun 30, 2003. Later-represents the sample period after the TWSE changed the tick size rule, the period between Feb 26, 2007 and Jul 18, 2007. $\lambda, \varphi, \gamma$, and $\alpha$ are parameters from the Sandais (2001) model. $\tau$ is standardized adverse selection cost proposed by Hasbrouck (1991). All parameter values are the daily averages during the sample period, while the parameter values of grouped samples are derived from averaging the means of individual samples.

*** denotes significance at the 0.01 levels. T-statistics are in parentheses.

Table 6 shows the results for the proxy variables of informed trading, volatility and liquidity. We find that individual stock and market volatilities drop in the later-period, while the Amivest liquidity index increases, indicating an improvement of volatility and liquidity in the later-period. A comparison of the T50 and T100 groups reveals that the T50, which is composed of the top 50 stocks by market capitalization, has lower volatility and higher liquidity. However, the $\lambda$ and $\varphi$ of the T50 are also higher than those of the T100, as reported in Table 3 . These results strongly suggest a correlation between adverse selection and stocks' visibility, trading volume, and information content. The $R^{N B P}$ estimates suggest that the market is seller-motivated in the initial period, and buyer-motivated in the later period. The $R^{N B P}$ of the OTHER group, which comprises small stocks, is highest, indicating that investors prefer small-cap stocks in Taiwan's stock market. The average matching interval was consistently shortened in the later period among all groups, with that of the T50 being the shortest. 
Table 6. Estimated informed-trading variables classified by ETF category

\begin{tabular}{|c|c|c|c|c|c|c|}
\hline $\begin{array}{ll} & \text { Sample } \\
\text { Variables } & \\
\end{array}$ & \multicolumn{3}{|c|}{$\begin{array}{c}\mathrm{T} 50 \\
(\mathrm{~N}=4215 / \text { Initial, } \mathrm{N}=4291 / \text { Later- })\end{array}$} & \multicolumn{3}{|c|}{$\begin{array}{c}\text { OTHER } \\
(\mathrm{N}=19483 / \text { Initial- }, \mathrm{N}=20795 / \text { Later- })\end{array}$} \\
\hline Variable & Initial- $^{(1)}$ & Later- ${ }^{(2)}$ & (2)-(1) & Initial- $^{(1)}$ & Later- $^{(2)}$ & (2)-(1) \\
\hline $\begin{array}{r}\sigma^{\text {stock }} \\
\left(\times 10^{3}\right)\end{array}$ & $\begin{array}{c}20.22 \\
(202.15) * * *\end{array}$ & $\begin{array}{c}11.73 \\
(165.53) * * *\end{array}$ & $\begin{array}{c}-8.49 \\
(-69.43) * * *\end{array}$ & $\begin{array}{c}23.09 \\
(347.67) * * *\end{array}$ & $\begin{array}{c}18.07 \\
(285.25) * * *\end{array}$ & $\begin{array}{c}-5.03 \\
(-54.81) * * *\end{array}$ \\
\hline Liq $^{\text {Amivest }}$ & $\begin{array}{l}61732 \\
(37.89) * * *\end{array}$ & $\begin{array}{l}214655 \\
(49.36) * * *\end{array}$ & $\begin{array}{l}1.53 \times 10^{5} \\
(32.71) * * *\end{array}$ & $\begin{array}{c}7605 \\
(69.38) * * *\end{array}$ & $\begin{array}{l}20739 \\
(81.34) * * *\end{array}$ & $\begin{array}{l}13134 \\
(46.25) * * *\end{array}$ \\
\hline $\begin{array}{c}R^{N B P} \\
\left(\times 10^{2}\right) \\
\end{array}$ & $\begin{array}{l}-1.868 \\
(-1.71)\end{array}$ & $\begin{array}{l}7.522 \\
(7.15) * * *\end{array}$ & $\begin{array}{l}9.391 \\
(6.20) * * *\end{array}$ & $\begin{array}{c}-7.261 \\
(-15.75) * * *\end{array}$ & $\begin{array}{l}10.075 \\
(25.80) * * *\end{array}$ & $\begin{array}{l}17.340 \\
(28.82) * * *\end{array}$ \\
\hline Time $e^{\text {Matching }}$ & $\begin{array}{c}1.606 \\
(119.28) * * *\end{array}$ & $\begin{array}{c}1.025 \\
(123.08) * * *\end{array}$ & $\begin{array}{c}-0.582 \\
(-36.89) * * *\end{array}$ & $\begin{array}{c}3.067 \\
(258.47) * * *\end{array}$ & $\begin{array}{c}2.355 \\
(220.58) * * *\end{array}$ & $\begin{array}{c}-0.712 \\
(-44.73) * * *\end{array}$ \\
\hline $\begin{array}{l}R_{\text {MinTime }}^{\text {Informediader }} \\
\left(\times 10^{2}\right)\end{array}$ & $\begin{array}{c}18.615 \\
(180.97) \text { *** }\end{array}$ & $\begin{array}{c}16.206 \\
(132.93) * * *\end{array}$ & $\begin{array}{c}-2.409 \\
(-15.08) * * *\end{array}$ & $\begin{array}{c}28.914 \\
(359.06) * * *\end{array}$ & $\begin{array}{c}24.360 \\
(320.05) * * *\end{array}$ & $\begin{array}{c}-4.554 \\
(-41.13) * * *\end{array}$ \\
\hline $\begin{array}{l}R_{M i d}^{\text {InformedTader }} \\
\left(\times 10^{2}\right)\end{array}$ & $\begin{array}{c}68.697 \\
(500.30) * * *\end{array}$ & $\begin{array}{c}67.367 \\
(531.71) * * *\end{array}$ & $\begin{array}{l}-1.330 \\
(-7.12) * * *\end{array}$ & $\begin{array}{c}66.985 \\
(1065.86) * * *\end{array}$ & $\begin{array}{c}66.453 \\
(1210.93) * * *\end{array}$ & $\begin{array}{l}-0.532 \\
(-6.39) * * *\end{array}$ \\
\hline $\begin{array}{l}R_{\operatorname{Max}}^{\text {Informediader }} \\
\left(\times 10^{2}\right)\end{array}$ & $\begin{array}{c}0.386 \\
(15.74) * * *\end{array}$ & $\begin{array}{c}0.619 \\
(19.22) * * *\end{array}$ & $\begin{array}{l}0.233 \\
(5.73) * * *\end{array}$ & $\begin{array}{c}1.046 \\
(53.32) * * *\end{array}$ & $\begin{array}{c}1.847 \\
(73.22) * * *\end{array}$ & $\begin{array}{c}0.801 \\
(24.83) * * *\end{array}$ \\
\hline $\begin{array}{ll}\text { Variables } & \text { Sample } \\
\end{array}$ & $(\mathrm{N}=78$ & $\begin{array}{c}\mathrm{T} 100 \\
\text { Initial-, } \mathrm{N}=82 \\
\end{array}$ & & $(\mathrm{~N}=31$ & $\begin{array}{c}\text { FULL } \\
\text { hitial-, N=333 }\end{array}$ & ater-) \\
\hline $\begin{array}{c}\sigma^{\text {stock }} \\
\left(\times 10^{3}\right) \\
\end{array}$ & $\begin{array}{c}23.27 \\
(250.23) * * *\end{array}$ & $\begin{array}{c}15.72 \\
(205.60) * * *\end{array}$ & $\begin{array}{c}-7.56 \\
(-63.06) * * *\end{array}$ & $\begin{array}{c}22.75 \\
(461.70) * * *\end{array}$ & $\begin{array}{c}16.67 \\
(360.50) * * *\end{array}$ & $\begin{array}{c}-6.085 \\
(-90.15) * * *\end{array}$ \\
\hline Liq ${ }^{\text {Amivest }}$ & $\begin{array}{l}26703 \\
(46.15) * * *\end{array}$ & $\begin{array}{l}57747 \\
(61.67) * * *\end{array}$ & $\begin{array}{l}31044 \\
(27.83) * * *\end{array}$ & $\begin{array}{l}19585 \\
(67.81) * * *\end{array}$ & $\begin{array}{l}54862 \\
(76.67) * * *\end{array}$ & $\begin{array}{l}35277 \\
(44.77) * * *\end{array}$ \\
\hline $\begin{array}{c}R^{N B P} \\
\left(\times 10^{2}\right) \\
\end{array}$ & $\begin{array}{l}-6.736 \\
(-8.93) * * *\end{array}$ & $\begin{array}{c}7.416 \\
(10.53) * * *\end{array}$ & $\begin{array}{l}14.150 \\
(13.73)^{* * *}\end{array}$ & $\begin{array}{c}-6.410 \\
(-17.28) * * *\end{array}$ & $\begin{array}{c}9.086 \\
(27.63) * * *\end{array}$ & $\begin{array}{l}15.500 \\
(31.34)^{* * *}\end{array}$ \\
\hline Time $e^{\text {Matching }}$ & $\begin{array}{c}2.180 \\
(142.93) * * *\end{array}$ & $\begin{array}{c}1.496 \\
(134.75) * * *\end{array}$ & $\begin{array}{c}-0.684 \\
(-36.56) * * *\end{array}$ & $\begin{array}{c}2.651 \\
(294.38) * * *\end{array}$ & $\begin{array}{c}1.970 \\
(252.55) * * *\end{array}$ & $\begin{array}{c}-0.681 \\
(-57.34) * * *\end{array}$ \\
\hline$R_{\substack{\text { MinTime } \\
\left(\times 10^{2}\right)}}^{\text {Informediader }}$ & $\begin{array}{c}21.991 \\
(202.12) * * *\end{array}$ & $\begin{array}{l}18.000 \\
(197.18) * * *\end{array}$ & $\begin{array}{c}-3.991 \\
(-28.22) * * *\end{array}$ & $\begin{array}{l}25.817 \\
(412.42) * * *\end{array}$ & $\begin{array}{l}21.732 \\
(374.98) * * *\end{array}$ & $\begin{array}{l}-4.085 \\
(-47.96) * * *\end{array}$ \\
\hline $\begin{array}{l}R_{M i d}^{\text {Informeditader }} \\
\left(\times 10^{2}\right)\end{array}$ & $\begin{array}{c}67.587 \\
(667.13) * * *\end{array}$ & $\begin{array}{c}67.297 \\
(722.04) * * *\end{array}$ & $\begin{array}{l}-0.290 \\
(-2.11) * *\end{array}$ & $\begin{array}{c}67.363 \\
(1350.27) * * *\end{array}$ & $\begin{array}{c}66.780 \\
(1502.46) * * *\end{array}$ & $\begin{array}{l}-0.583 \\
(-8.75) * * *\end{array}$ \\
\hline$R_{\left(\times 10^{2}\right)}^{\text {InformedTader }}$ & $\begin{array}{c}0.789 \\
(29.32) * * *\end{array}$ & $\begin{array}{c}1.174 \\
(36.51) * * *\end{array}$ & $\begin{array}{l}0.385 \\
(9.12) * * *\end{array}$ & $\begin{array}{c}0.894 \\
(62.59) * * *\end{array}$ & $\begin{array}{c}1.522 \\
(83.28) * * *\end{array}$ & $\begin{array}{c}0.628 \\
(26.86) * * *\end{array}$ \\
\hline $\begin{array}{l}\sigma^{\text {market }} \\
\left(\times 10^{3}\right)\end{array}$ & & & & $\begin{array}{c}9.86 \\
(642.66) * * *\end{array}$ & $\begin{array}{c}4.64 \\
(494.09) * * *\end{array}$ & $\begin{array}{c}-5.22 \\
(-293.52) * * *\end{array}$ \\
\hline
\end{tabular}

Note. ETF samples represent the grouping of valid samples by ETF attribute into T50, T100, OTHER and FULL.

Initial- represents the sample period before the TWSE changed the tick size rule, the period between Feb 6, 2003 and Jun 30, 2003. Later- represents the sample period after the TWSE changed the tick size rule, the period between Feb 26, 2007 and Jul 18, 2007. All estimators are the daily average during the sample period, while the estimators of grouped samples are derived from averaging the means of individual samples. $\sigma^{\text {market }}, \sigma^{\text {stock }}$, Liq $^{\text {Amivest }}$, and $R^{N B P}$ are market volatility, stock volatility, Amivest liquidity ratio and net buying pressure ratio, respectively. The informed-trader proxy variables are, respectively, trading interval (Time ${ }^{\text {Matching }}$ ), trading interval ratio ( $R_{\text {MinTime }}^{\text {InformedTader }}$ ), an order ratio with quantity within one standard deviation from the means of the interval ( $R_{\text {Mid }}^{\text {InformedTnder }}$ ) and the highest order quantity ratio ( $\left.R_{\text {Max }}^{\text {InformedTader }}\right)$.

***,**, and $*$ denote significance at the 0.01, 0.05, and 0.1 levels, respectively. T-statistics are in parentheses. 
Table 7. Correlation between parameter estimates and informed-trading variables for full sample

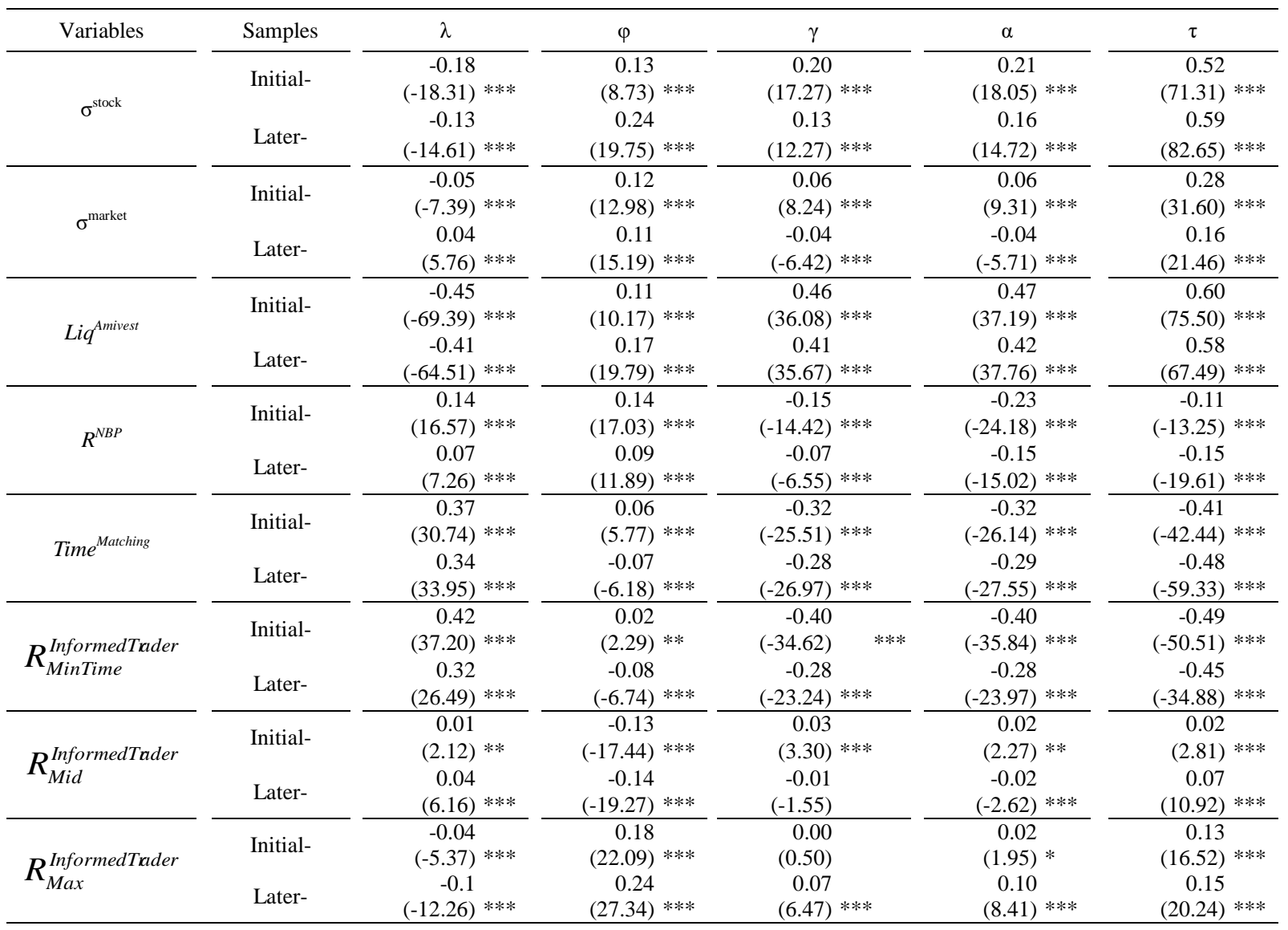

Note. Initial-represents the sample period before the TWSE changed the tick size rule, the period between Feb 6 , 2003 and Jun 30, 2003, 2003. Later-represents the sample period after the TWSE changed the tick size rule, the period between Feb 26, 2007 and Jul 18, 2007. All estimates are the daily averages during the sample period, while the estimates of grouped samples are derived from averaging the means of individual samples. $\sigma^{\text {market }}$, $\sigma^{\text {stock }}$, Liq ${ }^{\text {Amivest }}$, and $R^{N B P}$ are market volatility, stock volatility, Amivest liquidity ratio and net buying pressure ratio, respectively. The informed-trader proxy variables are, respectively, trading interval (Time ${ }^{\text {Matching }}$ ), trading interval ratio $\left(R_{\text {MinTime }}^{\text {InformedTader }}\right)$, an order ratio with quantity within one standard deviation from the means of the interval ( $R_{\text {Mid }}^{\text {InformedTader }}$ ) and the highest order quantity ratio $\left(R_{\text {Max }}^{\text {InformedTader }}\right)$.

***,**, and * denote significance at the 0.01, 0.05, and 0.1 levels, respectively. T-statistics are in parentheses.

We use Pearson correlation coefficients, as reported in Table 7, to investigate how orders from informed traders are related to estimated parameters. As shown, $\alpha$ and $\tau$ are negatively related to Time ${ }^{\text {Matching }}$ and $R_{\text {MinTime }}^{\text {InformedTader }}$, indicating an unreasonable situation where the shorter the trading interval and the smaller the order size of the minimum matching interval, the higher the $\alpha$ and $\tau$. In addition, the negative relations between $R^{N B P}$ estimates and $\alpha, \tau$ and $\gamma$ imply that a fall in net buyer-motivated trading volume would increase trading costs. We also find that both $R_{\text {Max }}^{\text {InformedTader }}$ and $R_{\text {Mid }}^{\text {InformedTader }}$ have statistically significant positive relations with $\alpha$ and $\tau$. 
Although $R_{\text {Mid }}^{\text {InformedTader }}$ is negatively related to $\alpha$ in the later period, $R_{\text {Mid }}^{\text {InformedTader }}$ is positively related to $\tau$, implying that informed traders tend to submit large-size or medium-size orders.

Several studies report that informed traders reduce their order size after tick size reduction. Thus, we use tick size variation to study the informed trader proxy variables. As done in Table 5, we classify the samples into three groups in Table 8: Decrease, Unchanged, and Increase.

As shown in Table $8, R_{\text {Mid }}^{\text {InformedTnder }}$ decreases significantly and the magnitude of decrease is highest in the Decrease group, reaching 0.733 . The $R_{\text {Max }}^{\text {InformedTader }}$ increases in all groups, differing from the finding of lower adverse selection cost after tick size reduction, as reported in Table 5. The average $R_{\text {Mid }}^{\text {InformedTader }}$ decreases in the Unchanged and Increase groups. However, as mentioned earlier, besides tick size reduction, increased information transparency and stock visibility also help to lower the adverse selection cost. These findings are consistent with those in Table 5. Thus, our empirical results support the stealth trading hypothesis rather than the notion that informed traders tend to place large-size orders. In Table 6, it is found that the decrease in

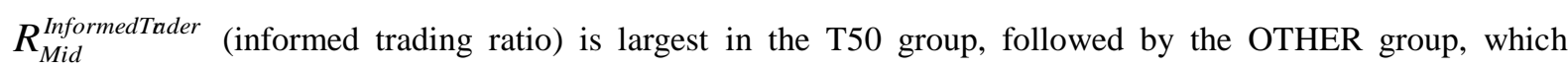
comprises small stocks. In Table 8, later-period samples with a tick size reduction show the highest volatility and net buying pressure, suggesting that investors switch to placing orders, in particular buy orders, on stocks with a tick size reduction to avoid incurring high adverse selection cost.

Across the three trading intervals, the daily volatilities of individual stocks tend to drop while individual stock liquidity tends to decrease during the day. The daily average matching interval (Time ${ }^{\text {Matching }}$ ) is first shortened as trading hours elapse, then lengthened as the market approaches the close. The intraday movement $R_{\text {Mid }}^{\text {InformedTader }}$ varies little. However, if we multiply $R_{\text {Mid }}^{\text {InformedTader }}$ by $\lambda$ and $\varphi$ to obtain the sum of informed orders $(\Sigma)$, we find that $\Sigma$ displays an upward and then downward trend over time. These results are reported in Table 9.

In reference to the parameter estimates in Table 4 , the $\tau$ of session $A$ is highest, but its $\mathrm{R}_{\text {Mid }}$ is lowest, which seems incongruous. Under the stealth trading hypothesis, this finding was reasonable. We think that after informed traders begin placing orders at the market open, information is gradually revealed over time so that increasing order size on the part of informed traders cannot increase adverse selection further because investors have the ability to learn and adapt.

The volatility, liquidity and order placement behavior of informed traders changes over time. Following Sandås (2001), we use individual stock volatility to capture the arrival rate of stock-specific information, and the volatility of TAIEX as a proxy to measure the arrival rate of market information. We use liquidity to gauge trading activity. As in Sandås (2001), we run the following linear regressions to assess the relationship between the informed-trading variables and parameter estimates:

$$
\begin{aligned}
& \alpha_{i, t}=\beta_{0}^{\alpha}+\beta_{1}^{\alpha} \sigma_{i, t}^{\text {stock }}+\beta_{2}^{\alpha} \sigma_{i, t}^{\text {market }}+\beta_{3}^{\alpha} \log \left(\text { Liq }_{i, t}^{\text {Amivest }}\right)+v_{\alpha} \\
& \gamma_{i, t}=\beta_{0}^{\gamma}+\beta_{1}^{\gamma} \sigma_{i, t}^{\text {stock }}+\beta_{2}^{\gamma} \sigma_{i, t}^{\text {market }}+\beta_{3}^{\gamma} \log \left(\operatorname{Liq}_{i, t}^{\text {Amivest }}\right)+v_{\gamma}
\end{aligned}
$$

where $\beta$ 's are coefficients and v's the error terms. The liquidity estimate is in logarithm to account for its large 
magnitude so that the coefficient estimates are of similar magnitude.

Because our samples contain cross-sectional data and time-series data, we adopt a panel data (PD) model to validate the regression results discussed above. We use the Hausman test to choose between the fixed effects and random effects by testing whether the ordinary least square estimation under the fixed effects are superior to the generalized least square estimation under the random effects.

Because the PD model requires balanced data, we eliminate 360 firms whose GMM estimates cannot converge, and obtain 171 sample firms, with each having parametric data across 100 days. Table 10 shows the results of the PD model. As shown, all F-values are statistically significant, suggesting a good fit of the PD model to our data. The Hausman test values also display statistical significance, indicating that our PD model is a fixed effects model.

Table 8 . Estimated informed-trading variables classified by tick size change

\begin{tabular}{|c|c|c|c|c|c|c|c|c|c|}
\hline \multirow{2}{*}{$\frac{\text { Tick size Change }}{\text { Variable }}$} & \multirow[b]{2}{*}{ Initial- ${ }^{(1)}$} & \multirow{2}{*}{$\frac{\text { Decrease }}{\text { Later- }^{(2)}}$} & \multirow[b]{2}{*}{ (2)-(1) } & \multicolumn{3}{|c|}{ Increase } & \multicolumn{3}{|c|}{ Unchanged } \\
\hline & & & & Initial- $^{(1)}$ & Later- $^{(2)}$ & (2)-(1) & Initial- $^{(1)}$ & Later- $^{(2)}$ & (2)-(1) \\
\hline$\sigma^{\text {stock }}$ & 22.94 & 17.35 & -5.59 & 24.26 & 16.94 & -7.32 & 22.45 & 16.17 & -6.28 \\
\hline$\left(\times 10^{3}\right)$ & $(279.08)^{* * * *}$ & $(203.51)^{* * *}$ & $(-47.17)^{* * *}$ & $(129.97)^{* * * *}$ & $(99.82)^{* * *}$ & $(-29.09)^{* * *}$ & $(346.88)^{* * * *}$ & $(290.73)^{* * *}$ & $(-73.92)^{* * *}$ \\
\hline \multirow{2}{*}{ Liq $^{\text {Amivest }}$} & 21853 & 31375 & 9522 & 13494 & 139753 & $1.26 \times 10^{5}$ & 18630 & 61690 & 43059 \\
\hline & $(46.88)^{* * *}$ & $(61.19)^{* * *}$ & $(13.72)^{* * *}$ & $(22.10) * * *$ & $(26.72)^{* * *}$ & $(23.28)^{* * *}$ & $(46.29)^{* * *}$ & $(57.92)^{* * *}$ & $(36.73)^{* * *}$ \\
\hline \multirow{2}{*}{$\begin{array}{c}R^{N B P} \\
\left(\times 10^{2}\right)\end{array}$} & -7.971 & 14.345 & 22.320 & -14.920 & 1.314 & 16.240 & -4.338 & 6.326 & 10.660 \\
\hline & $(-13.68)^{* * * *}$ & (28.72) & $(29.14)^{* * *}$ & $(-10.38)^{* * * *}$ & $(0.97)^{* * *}$ & $(8.21)^{* * *}$ & $(-8.52)^{* * *}$ & $(13.89)^{* * *}$ & $(15.66)^{* * *}$ \\
\hline \multirow[t]{2}{*}{ Time $e^{\text {Matching }}$} & 2.599 & 2.247 & -0.352 & 2.711 & 1.630 & -1.081 & 2.682 & 1.818 & -0.864 \\
\hline & $(184.18)^{* * * *}$ & $(164.20)^{* * * *}$ & $(-17.93)^{* * * *}$ & $(75.91)^{* * *}$ & $(52.69)^{* * *}$ & $(-22.96) * * *$ & $(216.98)^{* * *}$ & $(189.66)^{* * *}$ & $(-55.71)^{* * *}$ \\
\hline \multirow{2}{*}{$\begin{array}{c}R_{\text {MinTime }}^{\text {InformedTader }} \\
\left(\times 10^{2}\right)\end{array}$} & 25.199 & 23.520 & -1.678 & 26.034 & 19.196 & -6.838 & 26.239 & 20.782 & -5.457 \\
\hline & $(257.14)^{* * * *}$ & $(235.43)^{* * *}$ & $(-11.99) * * *$ & $(104.84)^{* * * *}$ & $(85.03)^{* * * *}$ & $(-20.42) * * *$ & $(305.58)^{* * * *}$ & $(285.05)^{* * *}$ & $(-48.68)^{* * *}$ \\
\hline \multirow{2}{*}{$\begin{array}{l}R_{\text {Mid }}^{\text {InformedTader }} \\
\quad\left(\times 10^{2}\right) \\
\end{array}$} & 67.290 & 66.557 & -0.733 & 67.302 & 66.688 & -0.615 & 67.423 & 66.944 & -0.479 \\
\hline & $(837.72) * * *$ & $(934.63)^{* * * *}$ & $(-6.84)^{* * * *}$ & $(339.96) * * *$ & $(382.55)^{* * * *}$ & $(-2.34)^{* *}$ & $(1003.23)^{* * *}$ & $(1113.40)^{* * *}$ & $(-5.33)^{* * *}$ \\
\hline \multirow{2}{*}{$\begin{array}{l}R_{\left(\times 10^{2}\right)}^{\text {InformedTader }} \\
\end{array}$} & 0.950 & 1.879 & 0.929 & 0.864 & 1.295 & 0.431 & 0.858 & 1.301 & 0.444 \\
\hline & $(39.64)^{* * *}$ & $(55.77)^{* * *}$ & $(22.37)^{* * * *}$ & $(16.96)^{* * *}$ & $(19.59)^{* * *}$ & $(5.12)^{* * *}$ & $(45.55)^{* * *}$ & $(59.28)^{* * *}$ & $(15.24)^{* * *}$ \\
\hline
\end{tabular}

Note. The estimated informed-trading variable are classified by the TWSE tick size change into three groups: decrease, increase and unchanged. Initial-represents the sample period before the TWSE changed the tick size rule, the period between Feb 6, 2003 and Jun 30, 2003. Later-represents the sample period after the TWSE changed the tick size rule, the period between Feb 26, 2007 and Jul 18, 2007. All estimates are the daily averages during the sample period, while the estimates of grouped samples are derived from averaging the means of individual samples. $\sigma^{\text {stock }}$, Liq ${ }^{\text {Amivest }}$ and $R^{N B P}$ are stock volatility, Amivest liquidity ratio and net buying pressure ratio, respectively. The informed-trader proxy variables are, respectively, trading interval (Time ${ }^{\text {Matching }}$ ), trading interval ratio ( $\left.R_{\text {MinTime }}^{\text {InformedTader }}\right)$, an order ratio with quantity within one standard deviation from the means of the interval ( $\left.R_{\text {Mid }}^{\text {InformedTader }}\right)$ and the highest order quantity ratio ( $\left.R_{\text {Max }}^{\text {InformedTader }}\right)$.

***, **, and * denote significance at the 0.01, 0.05, and 0.1 levels, respectively. T-statistics are in parentheses. 
Table 9. Estimated intraday informed-trading variables for the full sample

\begin{tabular}{|c|c|c|c|c|c|c|c|c|c|}
\hline \multirow{2}{*}{$\begin{array}{c}\text { Session } \\
\text { Variable }\end{array}$} & \multicolumn{3}{|c|}{ A: 9:09-10:30 } & \multicolumn{3}{|c|}{ B: 10:30-12:00 } & \multicolumn{3}{|c|}{ C: $12: 00-13: 21$} \\
\hline & Initial- ${ }^{(1)}$ & Later- $^{(2)}$ & (2)-(1) & Initial- ${ }^{(1)}$ & Later- $^{(2)}$ & (2)-(1) & Initial- ${ }^{(1)}$ & Later- $^{(2)}$ & (2)-(1) \\
\hline$\sigma^{\text {stock }}$ & 16.69 & 12.06 & -4.63 & 13.15 & 9.10 & -4.05 & 12.79 & 8.38 & -4.41 \\
\hline$\left(\times 10^{3}\right)$ & $(342.64)^{* * *}$ & $(276.40) * * *$ & $(-70.98)^{* * *}$ & $(288.27)^{* * *}$ & $(241.67)^{* * *}$ & $(-68.75)^{* * *}$ & $*(290.97) * * *$ & $(258.28) * * *$ & $(-82.43)^{* * *}$ \\
\hline$\sigma^{\text {index }}$ & 9.96 & 4.68 & -5.29 & 10.11 & 4.72 & -5.38 & 9.98 & 4.66 & -5.32 \\
\hline$\left(\times 10^{3}\right)$ & $(552.13)^{* * *}$ & $(436.80) * * *$ & $(-261.00)^{* * *}$ & $(466.00)^{* * *}$ & $(394.44) * * *($ & $(-232.67)^{* * *}($ & $*(479.95) * * *$ & $(425.17)^{* * *}$ & $(-243.99) * * *$ \\
\hline \multirow{2}{*}{ Liq $q^{\text {Amivest }}$} & 11873 & 26809 & 14936 & 10382 & 24565 & 14183 & 9413 & 22747 & 13334 \\
\hline & $(65.03)^{* * *}$ & $(72.54) * * *$ & $(34.20)^{* * *}$ & $(57.83)^{* * *}$ & $(71.95)^{* * * *}$ & $(32.76)^{* * *}$ & $*(59.48)^{* * *}$ & $(68.25)^{* * *}$ & $(31.84)^{* * *}$ \\
\hline$R^{N B P}$ & -16.400 & 0.069 & 16.470 & -14.310 & 6.652 & 20.960 & -6.833 & 17.856 & 24.690 \\
\hline$\left(\times 10^{2}\right)$ & $(-35.62)^{* * *}$ & $(0.17)$ & $(27.17)^{* * *}$ & $(-23.44)^{* * *}$ & $(13.62)^{* * *}$ & $(27.04) * * *$ & $*(-11.59)^{* * *}$ & $(37.58) * * *$ & $(32.83)^{* * *}$ \\
\hline \multirow{2}{*}{ Time $e^{\text {Matching }}$} & 1.544 & 1.234 & -0.310 & 1.455 & 1.208 & -0.247 & 1.577 & 1.293 & -0.284 \\
\hline & $(522.24)^{* * *}$ & $(393.56)^{* * *}$ & $(-70.97)^{* * *}$ & $(500.52)^{* * *}$ & $(408.40)^{* * *}$ & $(-57.64)^{* * *}$ & $*(506.02) * * *$ & $(405.47)^{* * *}$ & $(-61.60)^{* * *}$ \\
\hline \multirow{2}{*}{$R_{\text {Mid }}^{\text {InformedTader }}\left(\times 10^{2}\right)$} & 66.298 & 65.938 & -0.360 & 66.934 & 66.807 & -0.127 & 67.345 & 67.038 & -0.307 \\
\hline & $(1069.04)^{* * *}($ & $(1240.68)^{* * *}$ & $(-4.43)^{* * *}$ & $(866.36)^{* * *}$ & $(1091.55)^{* * *}$ & $(-1.30)$ & $(869.42)^{* * *}$ & $(1109.43)^{* * *}$ & $(-3.16)^{* * *}$ \\
\hline \multirow{2}{*}{$\Sigma$} & 3123 & 2128 & -996 & 3930 & 2451 & -1479 & 3749 & 2417 & -1332 \\
\hline & $(73.45)^{* * *}$ & $(29.47) * * *$ & $(-11.33)^{* * *}$ & $(62.80)^{* * *}$ & $(28.13)^{* * * *}$ & $(-12.73)^{* * * *}$ & $*(82.23) * * *$ & $(34.65)^{* * *}$ & $(-14.56)^{* * *}$ \\
\hline
\end{tabular}

Note. Initial- represents the sample period before the TWSE changed the tick size rule, the period between Feb 6 , 2003 and Jun 30, 2003. Later-represents the sample period after the TWSE changed the tick size rule, the period between Feb 26, 2007 and Jul 18, 2007. All estimates are the daily averages during the sample period, while the estimates of grouped samples are derived from averaging the means of individual samples. $\sigma^{\text {stock }}$, Liq ${ }^{\text {Amivest }}$ and $R^{N B P}$ are stock volatility, Amivest liquidity ratio, and net buying pressure ratio, respectively. The informed-trader proxy variables are, respectively, trading interval (Time ${ }^{\text {Matching })}$ and an order ratio with quantity within one standard deviation from the means of the interval $\left(R_{\text {Mid }}^{\text {InformedTader }}\right) . \Sigma$ is $R_{\text {Mid }}^{\text {InformedTader }}$ multiplied by $\lambda$ and $\varphi$.

***, **, and * denote significance at the 0.01, 0.05, and 0.1 levels, respectively. T-statistics are in parentheses.

Table 10. Results of the base panel data model classified by ETF category

\begin{tabular}{|c|c|c|c|c|c|}
\hline \multirow{2}{*}{$\begin{array}{c}\text { ETF } \\
\text { Samples }\end{array}$} & \multirow{2}{*}{ Variables } & \multicolumn{2}{|c|}{ Initial-period } & \multicolumn{2}{|c|}{ Later-period } \\
\hline & & $\alpha$ & $\gamma$ & $\alpha$ & $\gamma$ \\
\hline \multirow{11}{*}{ Full } & & 0.0048 & -0.9213 & 0.0036 & -0.2721 \\
\hline & Intercept & $(28.45) * * *$ & $(-43.17) * * *$ & $(19.41)^{* * * *}$ & $(-18.48)^{* * * *}$ \\
\hline & stock & -0.0006 & -4.3943 & 0.0106 & 0.2232 \\
\hline & $\sigma$ & $(-0.46)$ & $(-26.72) * * *$ & $(7.71)^{* * *}$ & $(2.05)^{* *}$ \\
\hline & $\sigma^{\text {market }}$ & 0.0234 & 3.0960 & 0.0093 & 3.8093 \\
\hline & $\sigma$ & $(7.10) * * *$ & $(7.41)^{* * *}$ & $(1.86)^{*}$ & $(9.58)^{* * * *}$ \\
\hline & Lig Amivest & -0.0003 & 0.0349 & -0.0003 & 0.0146 \\
\hline & Liq & $(-34.76) * * *$ & $(29.34) * * *$ & $(-28.12)^{* * * *}$ & $(16.44)^{* * * *}$ \\
\hline & $\mathrm{R}^{2}$ & 0.7616 & 0.8503 & 0.7694 & 0.8277 \\
\hline & F Value & $267.67 * * *$ & $485.05 * * *$ & $306.59 * * *$ & $410.55^{* * *}$ \\
\hline & M Value & $22.02 * * *$ & $158.19 * * *$ & $27.37 * * *$ & $128.48 * * *$ \\
\hline \multirow{6}{*}{ T50 } & & 0.0047 & -1.0923 & 0.0029 & -0.3774 \\
\hline & Intercept & $(7.10) * * *$ & $(-19.30) * * *$ & $(10.04)^{* * * *}$ & $(-6.42)^{* * *}$ \\
\hline & & -0.0335 & -11.3826 & 0.0158 & 3.2950 \\
\hline & $\sigma^{\operatorname{sich}}$ & $(-3.58) * * *$ & $(-14.16) * * *$ & $(3.57)^{* * * *}$ & $(3.61)^{* * *}$ \\
\hline & $\sigma^{\text {market }}$ & 0.0734 & 4.5065 & -0.0037 & 9.4568 \\
\hline & $\sigma$ & $(4.15) * * *$ & $(2.97) * * *$ & $(-0.39)$ & $(4.73)^{* * *}$ \\
\hline
\end{tabular}




\begin{tabular}{|c|c|c|c|c|c|}
\hline & Liq $^{\text {Amivest }}$ & $\begin{array}{l}-0.0004 \\
(-6.90) * * *\end{array}$ & $\begin{array}{l}0.0878 \\
(17.63)^{* * *}\end{array}$ & $\begin{array}{l}-0.0002 \\
(-9.85)^{* * *}\end{array}$ & $\begin{array}{l}0.0163 \\
(3.19)^{* * *}\end{array}$ \\
\hline & $\mathrm{R}^{2}$ & 0.6335 & 0.8759 & 0.8598 & 0.8433 \\
\hline & F Value & $163.95 * * *$ & $670.06 * * *$ & $541.79 * * *$ & $445.25^{* * * *}$ \\
\hline & M Value & $5.81 *$ & $61.45^{* * *}$ & $4.98 *$ & $11.06^{* * *}$ \\
\hline \multirow{8}{*}{$\mathrm{T} 100$} & Intercept & $\begin{array}{l}0.0037 \\
(15.71) * * *\end{array}$ & $\begin{array}{l}-0.5061 \\
(-16.62) * * *\end{array}$ & $\begin{array}{l}0.0058 \\
(16.07)^{* * *}\end{array}$ & $\begin{array}{l}-0.4877 \\
(-17.95)^{* * *}\end{array}$ \\
\hline & $\sigma^{\text {stock }}$ & $\begin{array}{r}0.0042 \\
(1.40)\end{array}$ & $\begin{array}{l}-5.3720 \\
(-13.95)^{* * *}\end{array}$ & $\begin{array}{l}0.0089 \\
(1.99)^{* *}\end{array}$ & $\begin{array}{l}-1.6243 \\
(-4.79)^{* * *}\end{array}$ \\
\hline & $\sigma^{\text {market }}$ & $\begin{array}{l}0.0145 \\
(2.02) * *\end{array}$ & $\begin{array}{l}5.0093 \\
(5.41)^{* * * *}\end{array}$ & $\begin{array}{r}0.0161 \\
(1.14)\end{array}$ & $\begin{array}{l}4.7129 \\
(4.42)^{* * * *}\end{array}$ \\
\hline & Lia Amivest & -0.0003 & 0.0376 & -0.0004 & 0.0310 \\
\hline & & $(-14.46) * * *$ & $(14.15)^{* * *}$ & $(-11.70) * * *$ & $(12.69)^{* * *}$ \\
\hline & $\mathrm{R}^{2}$ & 0.8618 & 0.8854 & 0.7955 & 0.8230 \\
\hline & F Value & $561.14 * * *$ & $719.71 * * *$ & $382.08 * * *$ & $442.53^{* * *}$ \\
\hline & M Value & $12.39 * * *$ & $49.48 * * *$ & $5.30 *$ & $51.64 * * *$ \\
\hline \multirow{8}{*}{ Other } & Intercept & $\begin{array}{l}0.0048 \\
(45.53) * * *\end{array}$ & $\begin{array}{l}-0.8537 \\
(-43.55) * * *\end{array}$ & $\begin{array}{l}0.0035 \\
(20.03)^{* * *}\end{array}$ & $\begin{array}{l}-0.2062 \\
(-23.14)^{* * *}\end{array}$ \\
\hline & $\sigma^{\text {stock }}$ & 0.0010 & -3.2485 & 0.0106 & 0.6065 \\
\hline & & $(1.11)$ & $(-19.07)^{* * *}$ & $(7.78)^{* * *}$ & $(8.71)^{* * *}$ \\
\hline & $\sigma^{\text {index }}$ & $\begin{array}{l}0.0188 \\
(7.55) * * *\end{array}$ & $\begin{array}{l}1.9104 \\
(4.13) * * *\end{array}$ & $\begin{array}{l}0.0091 \\
(1.66)^{*}\end{array}$ & $\begin{array}{l}1.7935 \\
(6.38)^{* * * *}\end{array}$ \\
\hline & $\mathrm{Liq}^{\mathrm{Ami}}$ & $\begin{array}{l}-0.0003 \\
(-47.64) * * *\end{array}$ & $\begin{array}{l}0.0260 \\
(20.38)^{* * *}\end{array}$ & $\begin{array}{l}-0.0003 \\
(-25.62)^{* * *}\end{array}$ & $\begin{array}{l}0.0082 \\
(13.59)^{* * *}\end{array}$ \\
\hline & $\mathrm{R}^{2}$ & 0.7187 & 0.7566 & 0.7105 & 0.6332 \\
\hline & F Value & $192.87 * * *$ & $255.36 * * *$ & $216.12 * * *$ & 148.78 *** \\
\hline & M Value & $26.16 * * *$ & $127.34 * * *$ & $9.07 * *$ & $93.13 * * *$ \\
\hline
\end{tabular}

Note. ETF samples represent the grouping of valid samples by ETF attribute into T50, T100, Other and Full. Initial-represents the sample period before the TWSE changed the tick size rule, the period between Feb 6, 2003 and Jun 30, 2003. Later-represents the sample period after the TWSE changed the tick size rule, the period between Feb 26, 2007 and Jul 18, 2007. Dependent variables $\alpha$ and $\gamma$ are parameters from the Sandås (2001) model. Independent variables $\sigma^{\text {stock }}, \sigma^{\text {market }}$ and Liq $^{\text {Amivest }}$ are stock volatility, market volatility and Amivest liquidity ratio, respectively. $\beta^{\prime}$ s in model are regressive coefficients and $v$ is the error term.

$* * *, * *$, and $*$ denote significance at the $0.01,0.05$, and 0.1 levels, respectively. T-statistics are in parentheses.

Here is a summary of the results in Table 10. For the $\alpha$ equation, the table shows that individual stock and market volatilities have a consistently positive influence on $\alpha$, and the higher the liquidity, the lower the adverse selection cost. For the $\gamma$ equation, the coefficient estimates show that liquidity and market volatility have a consistently positive influence on $\gamma$. As for the individual stock volatility, with the exception of the T100, the $\beta_{1}^{\gamma}$ changes from negative in the initial period to positive in the later period. These results indicate that a rise in volatility increases the possibility of informed trading, which further increases the adverse selection cost and order submission cost. On the other hand, a rise in liquidity results in a decrease in informed trading, which leads to lower adverse selection and monitoring costs. (Note 17) We also notice that the intercepts of the PD model approximate the GMM parameter estimators. For example, $\beta_{0}^{\gamma}=-0.3774$ and $\beta_{0}^{\alpha}=0.0029$ of the later-T50 sample is very close to the GMM estimator of $\gamma=-0.3442$ and $\alpha=0.00103$ in Table 3 .

In our final analysis, we investigate the influence of an informed trader's order submission behavior on $\tau$. To account for possible collinearity among variables with potential impacts on $\tau$, we employ a two-stage regression analysis. First we use $\mathrm{Liq}^{\text {Amivest }}$ as a dependent variable to run the following regression for each sample: 


$$
\log \left(\text { Liq }_{t}^{\text {Amivest }}\right)=\delta_{0}+\delta_{1} \sigma_{t}^{\text {stock }}+\delta_{2} \sigma_{t}^{\text {market }}+\delta_{3} Q S_{t}+\delta_{4} R_{t}^{N B P}+v_{t}
$$

where $\delta$ is a regression coefficient and $v$ is an error term, which represents incremental information on liquidity, while QS is the bid-ask spread of the first best quote, which is like tick size. (Note 18) In the second-stage regression, we use $v$ as a liquidity proxy variable to prevent collinearity between variables. We add a dummy variable of period, an intercept dummy variable, and an interaction dummy variable for the slope of informed trading in the regression model below:

$$
\begin{aligned}
\tau_{i, t}=\tau_{0} & +\tau_{1} D_{i, t}+\tau_{2} R_{i, t}^{\text {InformedTrading }}+\tau_{3} D_{i, t} \times R_{i, t}^{\text {InformedTrading }} \\
& +\tau_{4} Q S_{i, t}+\tau_{5} R_{i, t}^{N B P}+\tau_{6} \sigma_{i, t}^{\text {stock }}+\tau_{7} \sigma_{i, t}^{\text {market }}+\tau_{8} v_{i, t}+\varepsilon_{\tau}
\end{aligned}
$$

where $\mathrm{D}$ is a dummy variable that takes the value 1 for the initial period, and zero otherwise, $\tau$ and $\varepsilon$ are, respectively, a coefficient and error term, and i and t represent, respectively, firm i and time. $R^{\text {InformedTrading }}$ is the ratio of informed orders, which includes large-quantity orders and medium-quantity orders.

Table 11 reports the results of the PD modeling in the second stage, as summarized below. First, control variables volatility and NBP have a positive influence on $\tau$, as predicted theoretically. Further, the test statistics of coefficients are statistically significant. Incremental information on liquidity also has a positive influence on $\tau$, indicating that incremental liquidity would encourage informed traders to trade, resulting in increased adverse selection cost. Coefficient $\tau_{2}$ is significantly negative, suggesting the special nature of the tick size of TWSE stocks. Because stocks with larger tick sizes have higher transaction prices, while high-price TWSE stocks are typically well-known stocks that are T50 constituents and highly liquid, QS has a negative influence on $\tau$. Interesting as these results might be, our focus is on the performance of the informed-trader proxy variables and dummy variables in the models. As anticipated, $\tau_{1}$ in both models is negative with statistical significance, suggesting that the influences of variables are markedly different in the two periods. $\tau_{2}$ in both models is positive with statistical significance, consistent with the theoretical prediction. Finally, $\tau_{3}$ is positive with $R_{\text {Mid }}^{\text {InformedTrading }}$ being the informed-trading proxy variable, suggesting an increasing influence of $R_{\text {Mid }}^{\text {InformedTrading }}$ on $\tau$ in the later period, confirming the theoretical prediction. But $\tau_{3}$ is negative when $R_{\text {Max }}^{\text {InformedTrading }}$ is used as an informed-trading proxy variable, suggesting less influence of $R_{\text {Max }}^{\text {InformedTrading }}$ on $\tau$ in the later period, inconsistent with the order placement behavior of informed traders. Such a result coincides with the discussion above that informed traders engage in stealth trading. Thus, our empirical findings support the stealth trading hypothesis. 
Table 11. Results from the panel data model using dummy variables

\begin{tabular}{|c|c|c|}
\hline \multirow[b]{2}{*}{ Coefficient } & \multicolumn{2}{|c|}{ Informed-trading variables } \\
\hline & $R_{\text {Mid }}^{\text {InformedTrading }}$ & $R_{M a x}^{\text {InformedTrading }}$ \\
\hline \multirow{2}{*}{$\tau_{0}$} & 0.0000 & 0.0089 \\
\hline & $(0.00) * * *$ & $(3.66) * * *$ \\
\hline \multirow{2}{*}{$\tau_{1}$} & -0.0194 & -0.0030 \\
\hline & $(-9.33) * * *$ & $(-6.50) * * *$ \\
\hline \multirow{2}{*}{$\tau_{2}$} & 0.0142 & 0.0318 \\
\hline & $(6.81) * * *$ & $(4.30) * * *$ \\
\hline \multirow{2}{*}{$\tau_{3}$} & 0.0232 & -0.0841 \\
\hline & $(7.64) * * *$ & $(-9.22) * * *$ \\
\hline \multirow{2}{*}{$\tau_{4}$} & -6.5104 & -6.5073 \\
\hline & $(-64.21) * * *$ & $(-63.69) * * *$ \\
\hline \multirow{2}{*}{$\tau_{5}$} & -0.0047 & -0.0048 \\
\hline & $(-22.55) * * *$ & $(-22.99) * * *$ \\
\hline \multirow{2}{*}{$\tau_{6}$} & 3.3905 & 3.4166 \\
\hline & $(190.45) * * *$ & $(187.62) * * *$ \\
\hline \multirow{2}{*}{$\tau_{7}$} & 1.4445 & 1.3994 \\
\hline & $(24.70) * * *$ & $(23.89) * * *$ \\
\hline \multirow{2}{*}{$\tau_{8}$} & 0.0203 & 0.0203 \\
\hline & $(97.43) * * *$ & $(97.36) * * *$ \\
\hline $\mathrm{R}^{2}$ & 0.5559 & 0.5544 \\
\hline F-test & $17.81 * * *$ & $17.90 * * *$ \\
\hline Hausman Test & $95.53 * * *$ & $94.27 * * *$ \\
\hline
\end{tabular}

$$
\begin{aligned}
\tau_{i, t}=\tau_{0} & +\tau_{1} D_{i, t}+\tau_{2} R_{i, t}^{\text {InformedTrading }}+\tau_{3} D_{i, t} \times R_{i, t}^{\text {InformedTrading }} \\
& +\tau_{4} Q S_{i, t}+\tau_{5} R_{i, t}^{N B P}+\tau_{6} \sigma_{i, t}^{\text {stock }}+\tau_{7} \sigma_{i, t}^{\text {market }}+\tau_{8} v_{i, t}+\varepsilon_{\tau}
\end{aligned}
$$

Note. $D$ is a dummy variable that takes the value 1 for the initial period, and 0 otherwise. Initial-represents the sample period before the TWSE changed the tick size rule, the period between Feb 6, 2003 and Jun 30, 2003. Later-represents the sample period after the TWSE changed the tick size rule, the period between Feb 26, 2007 and Jul 18, 2007. $\tau$ and $\varepsilon$ are, respectively, the coefficient and error term, and $i$ and $t$ represent, respectively, firm $i$ and time. $R^{\text {InformedTrading }}$ is the ratio of informed orders, which includes large-quantity order

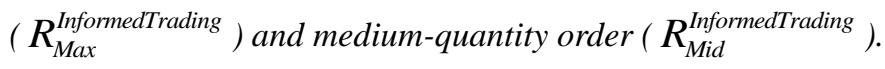

***,**, and * denote significance at the 0.01, 0.05, and 0.1 levels, respectively. T-statistics are in parentheses.

\section{Conclusion}

Our empirical results from a large Taiwanese sample show that the order book equilibrium model derived by Sandås (2001) can fully depict information-based behavior in an order-driven market. We find that investors prefer well-known stocks, and the high liquidity and low volatility of well-known stocks can offset adverse 
selection created by informed trading, leading to low adverse selection cost. Yet, those investors must incur high costs to monitor the order book when they place orders on well- known stocks.

Furthermore, our empirical results suggest that informed traders on the TWSE prefer to submit orders at the beginning and closing hours of the trading day, and that $t$ adverse selection has greatest impact at the beginning of the day, as suggested by the negative skew in the intraday unit price of adverse selection cost. This implies that informed traders tend to concentrate their trading at the beginning of the day. Our two-stage regression analysis with proxy variables for informed trading supports the stealth trading hypothesis rather than the claim that informed traders are large-order submitters.

Finally, under the special matching mechanism of an order-driven market, tick size reduction can lower adverse selection cost. But in a market that uses transaction price to determine tick size, such as the TWSE, tick size increase can also reduce adverse selection cost, mainly due to increased information transparency and investor preference. High-price, well-known stocks are often favored by investors, in particular, liquidity traders. For the TWSE-listed stocks, tick size increase implies rising stock price. When liquidity traders trade well-known stocks, their expected loss falls in anticipation that such stocks will become more recognizable. On the other hand, the expected profit of informed traders also falls, leading to lower possibility of adverse selection and lower adverse selection cost. Tick size reduction could lower the adverse selection cost and the cost of monitoring the order book.

Interesting as our results are, they are from a particular emerging market. Before generalizing the implications of these results, further analysis with data from other emerging markets might be warranted.

\section{References}

Andersen, T. G., \& Bollerslev, T. (1998). Answering the Skeptics: Yes, Standard Volatility Models Do Provide Accurate Forecasts. International Economic Review, 39, 885-905. https://doi.org/10.2307/2527343

Bagehot, W. (1971). The Only Game in Town. Financial Analysts Journal, 8, 31-53. https://doi.org/10.2469/faj.v27.n2.12

Baker, K. L. (1996). Trading Location and Liquidity. Financial Markets, Institution and Instruments, 5, 1-51.

Barclay, M. J., \& Warner, J. B. (1993). Stealth Trading and Volatility: Which Trades Move Prices? Journal of Financial Economics, 34, 281-305. https://doi.org/10.1016/0304-405X(93)90029-B

Bauwens, L., \& Giot, P. (2001). Econometric Modelling of Stock Market Intraday Activity. Kluwer Academic Publishers. https://doi.org/10.1007/978-1-4757-3381-5

Bauwens, L., \& Giot, P. (2003). Asymmetric ACD Model: Introducing Price Information in the ACD Model. Empirical Economics, 28, 1-23. https://doi.org/10.1007/s00181-003-0155-7

Bernstein, P. L. (1987). Liquidity, Stock Markets, and Market Makers. Financial Management, 16, 54-62. https://doi.org/10.2307/3666004

Bessembinder, H., Chan, K., \& Seguin, P. J. (1996). An Empirical Examination of Information, Differences of Opinion, and Trading Activity. Journal of Financial Economics, 40, 105-134. https://doi.org/10.1016/0304-405X(95)00839-7

Bisi ere, C., \& Kamionka, T. (2000). Timing of Orders, Orders Aggressiveness and the Order Book at the Paris Bourse. Annales d'Economie et de Statistique, 60, 43-72. https://doi.org/10.2307/20076255

Bloomfield, R., O'Hara, M., \& Saar, G. (2005). The Make or Take Decision in an Electronic Market: Evidence on the Evolution of Liquidity. Journal of Financial Economics, 75, 165-199. https://doi.org/10.1016/j.jfineco.2004.07.001

Bollen, N. P., \& Whaley, R. E. (2004). Does Net Buying Pressure Affect the Shape of Implied Volatility Functions. Journal of Finance, 59, 711-753. https://doi.org/10.1111/j.1540-6261.2004.00647.x

Bollen, N. P., Smith, T., \& Whaley, R. E. (2004). Modeling the Bid/Ask Spread: Measuring the Inventory-Holding Premium. Journal of Financial Economics, 72, 97-141. https://doi.org/10.1016/S0304-405X(03)00169-7

Chakravarty, S. (2001). Stealth Trading: Which Traders' Trades Move Stock Prices? Journal of Financial Economics, 61, 289-307. https://doi.org/10.1016/S0304-405X(01)00063-0

Chakravarty, S., Van Ness, B. F., \& Van Ness, R. A. (2005). The Effect of Decimalization on Trade Size and 
Adverse Selection Costs. Journal of Business Finance and Accounting, 32, 1063-1081. https://doi.org/10.1111/j.0306-686X.2005.00622.x

Chan, K. C., Christie, W. G., \& Schultz, P. H. (1995). Market Structure and the Intraday Pattern of Bid-Ask Spreads for NASDAQ Securities. Journal of Business, 68, 35-60. https://doi.org/10.1086/296652

Chen, Y. L., \& Gau, Y. F. (2009). Tick Sizes and Relative Rates of Price Discovery in Stock, Futures, and Options Markets: Evidence from the Taiwan Stock Exchange. Journal of Futures Markets, 29, 74-93. https://doi.org/10.1002/fut.20319

Comerton-Forde, C., \& Rydge, J. (2006). The current state of Asia-Pacific stock exchanges: A critical review of market design. Pacific-Basin Finance Journal, 14, 1-32. https://doi.org/10.1016/j.pacfin.2005.05.002

Copeland, T., \& Galai, D. (1983). Information Effects on the Bid-Ask Spread. Journal of Finance, 38, 1457-1469. https://doi.org/10.1111/j.1540-6261.1983.tb03834.x

Dubofsky, D. A., \& Growth, J. C. (1984). Exchange Listing and Stock Liquidity. Journal of Financial Research, 7, 291-302. https://doi.org/10.1111/j.1475-6803.1984.tb00381.x

Easley, D., \& O’Hara, M. (1987). Price, Trade Size and Information in Securities Markets. Journal of Financial Economics, 19, 69-90. https://doi.org/10.1016/0304-405X(87)90029-8

Easley, D., \& O'Hara, M. (1992). Time and the Process of Security Price Adjustment. Journal of Finance, 47, 577-605. https://doi.org/10.1111/j.1540-6261.1992.tb04402.x

Engle, R. F., \& Russell, J. (1998). Autoregressive Conditional Duration: A New Model for Irregularly Spaced Transaction Data. Econometrica, 66, 1127-1162. https://doi.org/10.2307/2999632

Foster, F., \& Viswanathan, S. (1993). Variations in trading volume, return volatility, and trading costs: Evidence on Recent Price Formation Models. Journal of Finance, 48, 157-186. https://doi.org/10.1111/j.1540-6261.1993.tb04706.x

Gibson, S., Singh, R., \& Yerramilli, V. (2003). The Effect of Decimalization on the Components of the Bid-ask Spread. Journal of Financial Intermediation, 12, 121-148. https://doi.org/10.1016/S1042-9573(03)00017-2

Giot, P., \& Laurent, S. (2004). Modeling Daily Value-at-Risk Using Realized Volatility and ARCH Type Models," Journal of Empirical Finance, 11, 379-398. https://doi.org/10.1016/j.jempfin.2003.04.003

Glosten, L. (1994). Is the Electronic Limit Order Book Inevitable? Journal of Finance, 49, 1127-1161. https://doi.org/10.1111/j.1540-6261.1994.tb02450.x

Glosten, L., \& Milgrom, P. (1985). Bid, Ask and Transaction Prices in a Specialist Market with Heterogeneously Informed Traders. Journal of Financial Economics, 14, 71-100. https://doi.org/10.1016/0304-405X(85)90044-3

Griffiths, M. D., Smith, B. F., Turnbull, A. S., \& White, R. W. (2000). The Costs and Determinants of Order $\begin{array}{lllll}\text { Aggressiveness. Journal of Financial } & \text { Economics, } & 56, & 65-88 .\end{array}$ https://doi.org/10.1016/S0304-405X(99)00059-8

Hansen, L. (1982). Large Sample Properties of Generalized Method of Moment Estimators, Econometrica, 50, 1029-1084. https://doi.org/10.2307/1912775

Harris, L. (1998). Does a Large Minimum Price Variation Encourage Order Exposure? Working Paper, University of Southern California.

Hasbrouck, J. (2004). Empirical Market Microstructure: Economic and Statistical Perspectives on the Dynamics of Trade in Securities Markets. Lecture notes for PhD seminar, Stern School of Business, NYU.

Huang, R., \& Stoll, H. (1994). Market Microstructure and Stock Return Predictions. Review of Financial Studies, 7, 179-213. https://doi.org/10.1093/rfs/7.1.179

Jain, P. (2001). Institutional Design and Liquidity on Stock Exchange. Working paper, Indiana University.

Jain, P., \& Joh, G. (1988). The Dependence Between Hourly Prices and Trading Volume. Journal of Financial and Quantitative Analysis, 23, 269-284. https://doi.org/10.2307/2331067

Kaniel, R., \& Liu, H. (2006). So What Orders Do Informed Traders Use? Journal of Business, 79, 1867-1913. https://doi.org/10.1086/503651

Ke, M., Jiang, C., \& Huang, Y. (2004). The Impact Of Tick Size On Intraday Stock Price Behavior: Evidence From The Taiwan Stock Exchange. Pacific-Basin Finance Journal, 12, 19-39. 
https://doi.org/10.1016/S0927-538X(03)00019-2

Madhavan, A. (1996). Security Prices and Market Transparency, Journal of Financial Intermediation, 5, 255-283. https://doi.org/10.1006/jfin.1996.0015

Martin, P. (1975). Analysis of Impact of Competitive Rates on the Liquidity of NYSE Stocks. Economics Staff Paper, Securities and Exchange Commission.

Massimb, M. N., \& Phelps, B. D. (1994). Electronic Trading, Market Structure, and Liquidity, Financial Analysts Journal, 50, 39-50. https://doi.org/10.2469/faj.v50.n1.39

Pagano, M., \& Roell, A. (1996). Transparency and Liquidity: A Comparison of Auction and Dealer Markets with Informed Trading, Journal of Finance, 51, 579-611. https://doi.org/10.1111/j.1540-6261.1996.tb02695.x

Sandås, P. (2001). Adverse Selection and Competitive Market Making: Empirical Evidence from a Limit Order Market, Review of Financial Studies, 14, 705-734. https://doi.org/10.1093/rfs/14.3.705

Schwartz, R. A. (1991). Reshaping the Equity Markets: A Guide for the 1990s. Harper Business.

Van Ness, B. F., \& Van Ness, R. A. (2005). The Impact of Market Maker Concentration on Adverse-selection Costs for NASDAQ Stocks. Journal of Financial Research, 28, 461-485. https://doi.org/10.1111/j.1475-6803.2005.00134.x

Zhao, X., \& Chung, K. H. (2006). Decimal Pricing and Information-Based Trading: Tick Size and Informational Efficiency of Asset Price. Journal of Business Finance \& Accounting, 33, 753-766. https://doi.org/10.1111/j.1468-5957.2006.00622.x

\section{Notes}

Note 1. Market makers have the obligation to provide quotes.

Note 2. Refer to Zhao and Chung (2006). The TWSE uses this matching rule.

Note 3. In Taiwan, investors often execute a limit order of limit up/down price as a market order.

Note 4. The TWSE has changed its transaction frequencies several times. Call auction was conducted twice every 90 seconds after 1999, and once every 20 seconds after 2012.

Note 5. To ensure price continuity, intra-day continuous auction was subject to the two up/down tick rule where the execution price was limited to two up/down ticks of the last executed price.

Note 6. In November 2007, the turnover was $135.1 \%$ at the NYSE, $67.61 \%$ at the HKEx, and $61.46 \%$ at the SGX.

Note 7. The TWSE changed the transaction frequencies from 2 min. to 90 seconds since November 2, 1993. Each stock can be executed 2 times at most in 90 seconds. In our sample periods, active stocks can be matched twice at least.

Note 8. OM acquired the Stockholm Stock Exchange in 1998. Sandås (2001)'s dataset consists of 59 trading days between Dec 3, 1991 and Mar 2, 1992.

Note 9. For instance, previous studies can only compare trading mechanisms of the call and continuous auction markets that co-exist in one market, or compare a real market with a simulated market.

Note 10. In 2003 and 2007, the TWSE opens respectively on Feb 2 and Feb 26 after the Chinese New Year. The same sampling period in different years can be avoided seasonality.

Note 11. This is because there are about 12 45-second call-back periods in the interval, which in most cases are sufficient to accommodate large intraday price moves so that the intraday price limit is not binding.

Note 12 . These are 50 of the most highly capitalized blue chip stocks, representing nearly $70 \%$ of the Taiwanese market. The index is the first of its kind designed specifically for derivative products in Taiwan

Note 13. The next 100 constituents ranked by market capitalization after the T50 Index. The T100 predominantly measures growth sectors and represents nearly $20 \%$ of the market.

Note 14. The measures are obtained by calculating the standard deviation of the number of shareholders in each percentage ownership group, which is formed by the number of shareholders in each category of shareholding at $10 \%$ increments.

Note 15. Low $\sigma$ means concentrated ownership. 
Note 16. The TWSE only accepts limit orders, but investors often execute a limit order of limit up/down price as a market order.

Note 17. Because the estimated monitoring cost is negative, a positive coefficient represents a negative correlation.

Note 18. The average correlation coefficient between Liq and $\sigma, \mathrm{QS}$ and NB in the sample period is, respectively, $0.46,0.4$, and 0.1 , and all are statistically significant. Thus, we treat Liq as an explained variable.

\section{Appendix A}

A Comparison of the Stockholm Stock Exchange (STO) and Taiwan Stock Exchange (TWSE)

\begin{tabular}{|c|c|c|c|c|c|c|c|}
\hline Year & Exchange & $\begin{array}{l}\text { Market Value } \\
\text { US\$ } \\
\text { (million) }\end{array}$ & $\begin{array}{l}\text { Turnover } \\
\text { Velocity } \\
(\%)\end{array}$ & $\begin{array}{l}\text { Market Value } \\
\text { Daily US\$ } \\
\text { (million) }\end{array}$ & $\begin{array}{l}\text { No of Traded } \\
\text { Shares Daily } \\
\text { (million) }\end{array}$ & $\begin{array}{l}\text { Listed } \\
\text { Companies }\end{array}$ & $\begin{array}{l}\text { Trading } \\
\text { Days }\end{array}$ \\
\hline \multirow{2}{*}{2003} & STO & 307,418 & 123.75 & 1,234 & 330 & 282 & -- \\
\hline & TWSE & 597,219 & 205.50 & 2,398 & 3,685 & 669 & 249 \\
\hline \multirow{2}{*}{2004} & STO & 472,041 & 134.00 & 1,865 & 328 & 277 & -- \\
\hline & TWSE & 732,597 & 206.09 & 2,930 & 3,950 & 697 & 250 \\
\hline \multirow{2}{*}{2005} & STO & 516,542 & 123.21 & 2,041 & 284 & 272 & 253 \\
\hline & TWSE & 590,165 & 127.27 & 2,389 & 2,686 & 691 & 247 \\
\hline \multirow{2}{*}{2006} & STO & 759,744 & 147.38 & 3,026 & 325 & 276 & 251 \\
\hline & TWSE & 736,528 & 133.97 & 2,969 & 2,953 & 688 & 248 \\
\hline \multirow{2}{*}{2007} & STO & 979,894 & 138.67 & 3,919 & 346 & 279 & 250 \\
\hline & TWSE & $1,014,969$ & 159.91 & 4,109 & 3,591 & 698 & 247 \\
\hline
\end{tabular}

Data source: World Federation of Exchanges (WFE).

\section{Copyrights}

Copyright for this article is retained by the author(s), with first publication rights granted to the journal.

This is an open-access article distributed under the terms and conditions of the Creative Commons Attribution license (http://creativecommons.org/licenses/by/4.0/). 